\title{
The remaining hydrocarbon potential of the UK Continental Shelf
}

J. W. Munns ${ }^{1}$, J.C. Gray ${ }^{1}$, S.J. Stoker ${ }^{2}$, I. J. Andrews ${ }^{2}$ and T.D.J. Cameron ${ }^{2}$

\author{
${ }^{1}$ Department of Trade and Industry, Licensing and Consents Unit, 2nd Floor 1 Victoria Street, London SW1H \\ 0ET (e-mail: Jim.Munns@dti.gsi.gov.uk; Joy.Gray@dti.gsi.gov.uk) \\ ${ }^{2}$ British Geological Survey, DTI Core Store, 376 Gilmerton Road, Edinburgh EH17 7QS (e-mail: \\ sjst@bgs.ac.uk,ija@bgs.ac.uk; tdjc@bgs.ac.uk)
}

\begin{abstract}
The United Kingdom Continental Shelf (UKCS) has been a very successful exploration province in the last 38 years, with an average technical success rate of $31 \%$ from its 2150 exploration wells. Though the peak of exploration activity on the UKCS occurred during the 1980s and 1990s, there have been 41 successes from 82 wells in the last four years, representing an improved recent success rate of $50 \%$.
\end{abstract}

Estimates of undiscovered (yet-to-find) hydrocarbon volumes have been made from a database of prospects compiled over 20 years by the UK Government. This 'bottom-up' method provided an estimate of the yet-tofind resources at the end of 2002 of between 3.6 and $22.9 \times 10^{9}$ BOE recoverable. Methodology utilising an inverse time scale to plot cumulative discovered volumes per year provides minimum estimates of between 4.5 and $9.5 \times 10^{9} \mathrm{BOE}$ in place (c. 2.5 to $4.4 \times 10^{9}$ BOE recoverable). Pool size distribution methodology predicts that $11.5 \times 10^{9} \mathrm{BOE}$ of in-place (c. $5.8 \times 10^{9} \mathrm{BOE}$ recoverable) resources remain to be found on the entire UKCS. Geographically, the UK Central North Sea and Moray Firth area is predicted to contain the largest proportion of undiscovered resources $(42 \%)$. Thirty-three percent of the yet-to-find resources are judged to lie within the Atlantic Margin region.

Eighty-three percent of existing UKCS fields and discoveries are located within structural traps. The majority of stratigraphic and combination traps occur in association with syn-rift (Upper Jurassic) and post-rift plays. Many of the major discoveries in these traps were found serendipitously, and there has been relatively little direct exploration for stratigraphic plays. In the UK North Sea, there are few substantial remaining structural traps, except at considerable depth with attendant reservoir quality, high pressure and high temperature risks. The 
future of exploration is believed to lie with the search for subtle stratigraphic traps. Deep-water sandstone stratigraphic plays within the syn- and post-rift sequences offer the greatest potential for substantial new resources.

\section{Keywords}

United Kingdom, North Sea, resource prediction, yet-to-find, play fairway, stratigraphic trap

The Department of Trade and Industry (DTI) publishes annual estimates of the UK's undiscovered (or yet-tofind) recoverable resources. At the end of 2002, these resources were estimated to be in the range $3.6-9-22.9$ x $10^{9}$ BOE (DTI 2003). Approximately $98 \%$ was predicted to occur on the UKCS (Fig. 1), the remainder being onshore. The central (P50) case, $9 \times 10^{9} \mathrm{BOE}$, comprises $5.3 \times 10^{9} \mathrm{BBL}$ oil and $18.8 \times 10^{12} \mathrm{SCF}$ gas (Table 1). At the end of 2001, the comparable undiscovered resources figure had been estimated to lie in the range $3.5-$ $26.1 \times 10^{9}$ BOE (DTI 2003).

The DTI has contracted the British Geological Survey through its Continental Shelf and Margins Programme to systematically map hydrocarbon prospectivity on the UKCS over the past 26 years. In areas where detailed mapping has been carried out, the yet-to-find resource is a 'bottom-up' estimate based on an inventory of risked prospects (or 'containers'). In other areas, principally the Rockall Basin, the figure is a best estimate using current knowledge.

The range of values published by the DTI reflects the level of uncertainty in estimating such figures, and the limits of these ranges should not be regarded as minima or maxima. The upside is poorly constrained because of the uncertainty in predicting volumes in stratigraphic traps, which remain difficult to resolve with any degree of confidence.

In this paper, the DTI compares the results of its future-looking, risked prospect inventory approach to yet-tofind estimation with 'top-down' methods that statistically analyse historical data on hydrocarbon basin performance. 
A comprehensive database of UKCS field and discovery volumes in each play has been used to construct discovery curve and pool size distribution plots. This database was derived from the DTI's listing of offshore producing and approved fields (DTI 2003), plus unpublished data from fields and drilled prospects for which there are no current plans for development (Potential Additional Reserves [PARs]). The database has been populated by hydrocarbon volumes originally in place, to negate the effects of variable recovery factors and the need to consider 'reserves growth'. The pool size classes are those used by the US Geological Survey (United States Geological Survey 1995).

Improved recovery offers significant potential for increasing recoverable reserves in existing fields. PILOT Taskforce (2001) identified 28 'brown field' (already developed) projects, which, with an average increase in recovery factor of $5 \%$, could produce an additional $4 \times 10^{9} \mathrm{BOE}$.

Discovery curves give a visual representation of the exploration maturity of an area or play. Data for the entire UKCS exhibit a maturing (rather than mature) signature, where the discovery rate may be declining, but significant discoveries are still being made (Fig. 2). A notable resurgence in 2001 was due to the discovery of the Buzzard oil field, which has an estimated 800-1100 x 106 BBL of oil in place (Doré \& Robbins 2004).

Exploration has become increasingly focused in recent years, driven by 3D seismic availability, global portfolio management and rigorous risk analysis. Exploration success can be judged by the number of discoveries per drilled exploration well (Fig. 3). The 1964-2002 average for the UKCS is a robust 31.1\%, i.e. 1 in 3.2. Despite a low level of exploration over the last four years, the average success rate for 1999-2002 is an impressive $50 \%$.

Comparison of discovery curves between basins or plays (Fig. 4) illustrates the individuality of each curve and the pulsed success signature shared by many plays.

The Northern, Central and Southern areas of the UK North Sea have quite different discovery curve signatures. The Northern North Sea has a rather mature profile (Fig. 4a), showing very rapid discovery of large resource volumes through the early 1970s and a relatively small increase in cumulative resources since then. The Central North Sea (including the Moray Firth Basin) shows generally high discovery levels up to the early 1990s (Fig. 4b), from which point the discovery curve shows a flatter, but not mature, profile with the step at 2001 produced by the discovery of the Buzzard Field. Likewise, the Southern North Sea discovery curve is not yet mature (Fig. 
4c); it shows a major rejuvenation between 1983-1985, due in large part to the discovery of the Ravenspurn and Galleon fields. The West of Shetland discovery curve is immature (Fig. 4d), with its largest steps represented by the discovery of the giant Clair Field in 1977 and of the Foinaven and Schiehallion fields in the early 1990s. The stepped appearance of all of these cumulative discovery curves is common to many basins worldwide as new exploration avenues are pursued in parallel with advancing technologies.

A discovery curve for the Middle Jurassic shallow marine/deltaic sandstones of the UKCS (exemplified by the world-class Brent Province fields) is illustrated as an example of a mature play (Fig. 4e). Ninety-four percent of this play’s known hydrocarbon volumes were discovered in structural traps in the 1970s, and mapping of the play is comprehensive, leaving little opportunity for it to be rejuvenated. A discovery curve for the Palaeogene deep-water sandstone play (Fig. 4f) has a distinctly immature shape, with a significant step spanning 1993-1994 caused largely by the discovery of the Foinaven and Schiehallion fields. The Lower Cretaceous deep-water play (Fig. 4g) found rejuvenated success in the late 1990s, with the discovery of fields such as Goldeneye and Blake. Similarly, the Upper Jurassic deep-water play has been enhanced by the giant Buzzard discovery; this followed a previous 'step up' in the mid-1980s when Miller and Devenick fields were discovered (Fig. 4h).

The plotting of cumulative discovered volumes per year on an inverse time scale (Fig. 5) allows linear extrapolation of the discovery rate to obtain an estimate of the UKCS's ultimate potential. However, discovery rates for two recent historical periods, 1984-1987 and 1987-1991 (Fig. 5), demonstrate how past estimates that could have been derived from this method have underestimated the ultimate potential due to subsequent discoveries. Thus, this method is pessimistic and the results should be treated as a minimum. The changes in discovery rate are due to the impact of new plays or technology exploitation e.g. Jurassic/ Triassic and Alba plays in the Central North Sea (1984-87) and the Palaeocene deep-water play West of Shetland (1987-91), the use of 3D seismic and the move to smaller and more subtle traps in various plays (1987-91). Using this approach, the minimum remaining undiscovered in-place resources at end 2002 are estimated to be $4.5 \times 10^{9}$ BOE $\left(2.1 \times 10^{9}\right.$ BOE recoverable) (Fig. 5). Construction of the most recent discovery rate line is heavily biased by the 2001 Buzzard discovery, and its extrapolation hinges on how this pattern continues. Using a 2000-2002 extrapolation, this method predicts an estimated $9.5 \times 10^{9} \mathrm{BOE}$ in place $\left(4.4 \times 10^{9} \mathrm{BOE}\right.$ recoverable). The question as to whether the Buzzard discovery is a one-off or the start of a new discovery trend is being tested by current exploration. 
Pool size distribution, or fractal methodology, pioneered by the US Geological Survey Resource Assessment team (United States Geological Survey 1995), can be used to estimate the number of fields in specified size classes that remain to be found. Using an economic cut-off of $4 \times 10^{6} \mathrm{BOE}$, this method predicts that $11.5 \times 10^{9}$ BOE of in-place resources (c. $5.8 \times 10^{9} \mathrm{BOE}$ recoverable) remain to be found in 644 discoveries on the entire UKCS (Fig. 6). Ten remaining fields in USGS Size Class 17 (256-512 $\times 10^{6} \mathrm{BBL}$ in place) are predicted by this method, but significantly, the majority of undiscovered fields are predicted to be relatively small in size (4-64 x $10^{6} \mathrm{BBL}$ in place). Few of these will be drilled, depending upon the balance of factors such as proximity to infrastructure, economic conditions, and development of new technology.

Using individual company prospect inventories, the United Kingdom Offshore Operators Association (UKOOA) (2003) estimate that there are $3.1 \times 10^{9} \mathrm{BOE}$ of recoverable resources within a total of 420 risked prospects in currently licensed acreage, with a further $3.9 \times 10^{9} \mathrm{BOE}$ in unlicensed acreage. Using less rigorous 'top-down' estimation methods, the operators estimate a range of $0.9-3.2-10.4 \times 10^{9} \mathrm{BOE}$ of recoverable resources (UKOOA 2003).

Geographically, the largest proportion of the DTI's published undiscovered recoverable resources is located in the Central North Sea-Moray Firth and Atlantic Margin regions (Table 2). UKOOA (2003) places a lower emphasis on the Atlantic Margin, and a higher proportion of undiscovered resources in its West of England, Wales, Irish Sea and English Channel region. The UKOOA (2003) estimates that 50\% of technical resources and $54 \%$ of commercial resources will be found in the Central North Sea area.

The fields, discoveries and undrilled prospects on the DTI database have been assigned to 43 specific plays. These have been simplified into 15 play groups to determine the relative importance of play type in existing and yet-to-find resources (Table 3). Comparison of the total hydrocarbon volume in known fields and discoveries in each play emphasizes the historical and current importance of the Middle and Upper Jurassic, Palaeogene and Lower Permian intervals (Table 3). A combination of methods (prospect inventory, field size distribution and regional knowledge) has been used to estimate the proportion of the UKCS's total yet-to-find that may be expected in each play (Table 3). Given the large number of uncertainties involved, these estimates should only be regarded as a guide to the relative significance of each play, and they should be viewed in conjunction with 
the large ranges quoted in the all-UKCS figure (e.g. the Upper Jurassic deep-water sandstone play may contain a further 0.8 to $5 \times 10^{9} \mathrm{BOE}$ recoverable).

Volumetrically, the Middle Jurassic shallow marine/deltaic play is the most important with respect to known UKCS fields and discoveries, containing $25.9 \%$ of the total estimated in-place resources. The Palaeogene deepwater, Upper Jurassic shallow marine/deltaic, and Permian aeolian plays contain 21\%, 11.9\% and $11.4 \%$ respectively of the estimated in-place total resources. Containing $8.3 \%$ of these resources, the Upper Jurassic deep-water play is the fifth most important. Looking towards the future, six plays are considered to offer the most significant exploration potential on the UKCS, each having $8 \%$ or more of the estimated yet-to-find volume (Table 3). The highest proportion of the UK's yet-to-find is projected to occur in the Palaeogene deep-water, Upper Jurassic deep-water, Lower Cretaceous deep-water, Upper Jurassic shallow marine/deltaic, Triassic to Lower Jurassic, and Carboniferous plays (Fig. 7). This projection is based in part upon the DTI's undrilled prospect inventory, but it is weighted by the premise that few substantial structural traps remain to be drilled, and that future targets are likely to be increasingly subtle.

\section{Plays of the future: the role of stratigraphic traps in exploration of the UKCS}

The majority of the oil and gas fields and discoveries to date on the UKCS are found in structural traps. Just $12 \%$ of fields and discoveries (19\% by volume) are found in combination structural/stratigraphic traps and only $5 \%$ ( $5 \%$ by volume) in stratigraphic traps (Figs. $8 \mathrm{a}$ and $8 \mathrm{~b}$ ). In existing fields and discoveries, the stratigraphic and combination traps occur mainly within Upper Jurassic syn-rift and Cretaceous to Palaeogene post-rift play fairways (Fig. 8c). Stratigraphic entrapment is less common in Middle Jurassic and older strata, because of the sheet-like geometry of many of the pre-rift reservoirs. Combination traps in the pre-rift plays generally involve major erosional truncation (e.g. Auk Field; Trewin \& Bramwell 1991). In contrast, stratigraphic entrapment in deep-water coarse clastics is an important component of the syn- and post-rift play fairways.

Historically, few stratigraphic traps have been the primary targets of exploration drilling on the UKCS, due to the higher level of risk and uncertainty and greater difficulty in identifying them on seismic data. Interestingly, a significant number of discoveries have been made in stratigraphic and combination traps through sheer good fortune during exploration or appraisal drilling to other, generally deeper, structural targets (e.g. Scapa, Alba). 
However, future exploration cannot rely on serendipity, and better techniques must be found for identifying subtle stratigraphic traps. Significantly, sophisticated seismic data analysis, in particular amplitude-versus-offset (AVO) techniques, has not proved to be entirely reliable on the UKCS, particularly within the Palaeogene deepwater sand play on the UK Atlantic Margin (Loizou 2002). The Buzzard Field discovered in 2001 (Doré \& Robbins 2004) is an Upper Jurassic stratigraphic pinch-out/dip trap on the margin of the Moray Firth Basin. It was found by applying traditional methods of seismic interpretation, and integrating well and other data, leading to the development of a strong conceptual model.

Of the six plays estimated to have the largest percentage of yet-to-find resources (Table 3), the Palaeogene, Lower Cretaceous and Upper Jurassic deep-water plays offer the greatest potential for stratigraphic and combination trap types. Though Upper Jurassic shallow marine/deltaic and Triassic to Lower Jurassic plays are also predicted to contain significant yet-to-find resources (Table 3), these will be mostly within deeply buried structural traps in the Central North Sea high pressure/high temperature regime. It is estimated that stratigraphic and combination traps will account for $33 \%$ of the yet-to-find resources in post-rift plays, $17 \%$ of the yet-to-find resources in syn-rift plays, and 5\% of the yet-to-find resources in pre-rift plays (Table 3). Hence, in total, some $55 \%$ of the UKCS yet-to-find resources are predicted within such traps.

\section{Pre-rift stratigraphic potential}

Carboniferous and Lower Permian plays are estimated to make up $8 \%$ and 7\% respectively of the UKCS yet-tofind resources (Table 3). Of existing pre-rift fields and discoveries, only 1-3\% rely on combination traps and there are no purely stratigraphic traps (Fig. 8c). The potential for pre-rift stratigraphic traps is limited, except in the Southern Gas Basin (Fig. 1) where such traps are largely unexplored within both the Carboniferous and Lower Permian fairways.

\section{$\underline{\text { Carboniferous }}$}

The majority of Southern Gas Basin Carboniferous gas discoveries lie within robust structural traps mapped at base Permian level, but many are complicated by significant dip, and by erosional truncation beneath a regional base Permian unconformity. The trap is ultimately controlled in most cases by the structural disposition of the overlying Permian mudstone and evaporite top seal. Largely untested potential remains for exploration of 
Carboniferous fluvio-deltaic sandstone reservoirs in those sub-Permian truncation traps where there is no structural closure at base Permian level, but where a Carboniferous intraformational seal performs critical lateral closure. Intraformational sealing intervals are common at three levels within the Upper Carboniferous: (i) an upper, shale-prone part of the Westphalian C-D Ketch Member forms a local seal to underlying Ketch Member sandstone and conglomerate reservoirs, (ii) the Westphalian B Westoe Coal Formation offers a regional seal to the basal Westphalian B Caister Sandstone unit, and (iii) thick basal Kinderscoutian basinal shales locally provide a seal to late Alportian sandstone reservoirs (Cameron et al. in press) (Fig. 9).

\section{$\underline{\text { Lower Permian }}$}

The principal reservoir in the Southern Gas Basin, the Lower Permian Leman Sandstone Formation, comprises aeolian and localized fluvial sandstones. Because of its broadly sheet-like, nearly basin-wide development, Leman Sandstone gas has been found almost exclusively within structural traps. The Ravenspurn North Field on the northern margin of the fairway is an important exception, comprising a combined structural and stratigraphic trap (Ketter 1991). On this margin of the Lower Permian fairway, a good reservoir quality aeolian dune facies interdigitates with sabkha facies and lacustrine shales of the Silverpit Formation. This sets up the potential for significant stratigraphic traps, particularly where aeolian sand distribution is related to palaeotopography (Fig. 10).

\section{Syn-rift stratigraphic potential}

Upper Jurassic syn-rift clastics include both shallow marine sandstones and deep-water mass-flow deposits. Shallow marine sandstones such as the Piper and Fulmar formations are mostly disposed in structural traps (e.g. Piper and Fulmar fields; Schmitt \& Gordon 1991; Stockbridge \& Gray 1991). There is only limited potential for further stratigraphic discoveries in syn-rift shallow marine reservoirs. However, the lateral distribution and geometry of syn-rift deep-water mass-flow deposits are highly conducive to at least partial stratigraphic entrapment, since they are interbedded with mudstones of the Kimmeridge Clay Formation, a world-class source rock that has generated much of the oil in the North Sea. Of the existing fields and discoveries with syn-rift reservoirs, 23\% are located in stratigraphic and combination traps (Fig. $8 \mathrm{c}$ ). 
Most of the syn-rift deep-water sandstone combination traps were initially drilled as structural traps (e.g. South Brae; Roberts 1991), but have proved to be larger than pre-drill prognosis because closure is enhanced by an element of stratigraphic pinch-out. The Brae trend fields in the South Viking Graben demonstrate the considerable success of the hanging-wall combination trap type, but remaining untested traps of this type are unlikely to have a significant structural component and will therefore be more difficult to identify. Many of those Upper Jurassic deep-water sandstone reservoirs that are purely within stratigraphic pinch-out traps occur above the flanks of an underlying structural trap, and were discovered through serendipity (e.g. Hot Lens reservoirs at Tartan and Highlander fields; Coward et al. 1991; Whitehead \& Pinnock 1991). At those fields, the Hot Lens sands were preferentially deposited within and thicken into topographic lows which developed in response to fault block rotation in the initial stages of the rift phase. Encasing shales of the Kimmeridge Clay Formation provide the trap seal.

Combination dip closure and stratigraphic pinch-out traps may occur both within and around the margins of the Upper Jurassic rift basins. Typically, such traps are subtle and may not be directly identifiable from seismic data, thus requiring the development of a well-grounded conceptual model. Recognition of wedging units, mounded intervals and amplitude anomalies within the syn-rift sequence may enhance the model, and lead to the identification of a prospect. An example of an undrilled intra-basinal lead in the Smith Bank Graben (Moray Firth) is illustrated in Figures 11a and 11b, and comprises up-dip pinch-out of an intra-Kimmeridgian wedging unit that is highlighted by the presence of a discrete amplitude anomaly (Lead 12/23 of DTI 2002). The Buzzard Field on the southern margin of the Moray Firth rift basins (Doré \& Robbins 2004) represents the first major discovery in a basin margin pinch-out play. With in-place resources estimated at $800-1100 \times 10^{6} \mathrm{BBL}$ of oil in place, Buzzard is the largest oil discovery to be made in the North Sea since 1984. Its size clearly demonstrates that those more subtle, complex traps remaining to be found are not necessarily smaller than existing structural traps. Similar up-dip pinch-out leads can be recognized along parts of the southern margin of the Moray Firth rift basins. The example shown in Fig. 11c is at a rather shallow depth of burial (about $550 \mathrm{~m}$ below sea bed), but shows good evidence of a mounded geometry at the pinch-out limit, with amplitude anomalies occurring at the up-dip pinch-out limit and adjacent to fault closure.

\section{Post-rift stratigraphic potential}


UKCS fields and discoveries within post-rift reservoirs contain the largest proportion of stratigraphic and combination traps $(49 \%$ overall), with the greatest ratio of stratigraphic/combination to structural traps recorded from the reservoirs of Lower Cretaceous age (Fig. 8c).

\section{$\underline{\text { Lower Cretaceous }}$}

Although the Early Cretaceous was a period of broadly post-rift style basin development, deep-water sandstones were deposited in response to local extensional faulting and inversion, probably under a strike-slip tectonic regime (Copestake et al. 2003). Sixty-one percent of UKCS Lower Cretaceous fields and discoveries are combination or stratigraphic traps (Fig. 8c). The serendipitous discovery of the Lower Cretaceous Scapa Field within a syncline during appraisal drilling of the underlying Upper Jurassic Claymore Field (McGann et al. 1991) exemplifies the importance of exploring within syn-sedimentary lows or synclines. This is a trap type that is not typically targeted in the early phase of exploration in a basin, but which comes to the fore as the basin matures.

Since seismic imaging of Lower Cretaceous sandstones is known to be poor (Law et al. 2000; Garrett et al. 2000), a sound depositional model must be built up from core and other well data in order to predict sand distribution, thickness and geometry, and hence to aid identification of potential stratigraphic traps. However, the increasing use of long offset seismic data with the attendant increase in bandwidth is proving an exciting exploration tool. Using such data, Morgan et al. (2002) showed that anomalous AVO gradients can be recognized within channel-like palaeo-lows in the far offset, 4-6 km range, and correlated this seismic response to the presence of sandstones.

Discoveries on the Lower Cretaceous play fairway are almost exclusively limited so far to the Moray Firth/Central North Sea area between Captain Field in Quadrant 13 and Britannia Field, which spans Quadrants 15 to 16 and 21 to 23 . The distribution of Lower Cretaceous sandstones is quite well constrained within the most heavily drilled parts of the Moray Firth, but is poorly constrained where wells are sparse, such as along the southern margin of the Moray Firth and within the largely undrilled depocentres of the Central Graben. In the southern part of the Central Graben, Lower Cretaceous sandstones or traces of sand have been found in a number of wells, and these can be used in conjunction with isochore/isochron maps derived from seismic interpretation 
to develop a model for their distribution. In the Late Ryazanian to Valanginian interval for instance, there is evidence from wells to suggest that most of the depocentres in the East and West Central Graben may contain deep-water sandstones shed off graben-margin highs (e.g. Auk High) and possibly also intra-basinal highs (e.g. Josephine High) (Fig. 12).

\section{$\underline{\text { Upper Cretaceous }}$}

Until recently, all of the UKCS Upper Cretaceous Chalk fields were believed to be structural traps (Johnson and Fisher 1998). However, Megson \& Hardman (2001) documented dipping oil-water contacts in the Chalk at the Joanne, Fife and Flora fields. In the Danish sector, the Halfdan Field is an unusual stratigraphic trap, where the body of oil in the Chalk reservoir is 'frozen' within its migration pathway (migration trap; Megson \& Hardman 2001). Recognition of stratigraphic and combination traps within the Upper Cretaceous requires the determination of migration entry points into the Chalk, estimation of maximum possible migration distance within the Chalk from the entry points, and preparation of palaeostructure maps relating to time(s) of oil emplacement (Megson \& Hardman 2001).

\section{$\underline{\text { Palaeogene }}$}

The majority of Palaeogene reservoirs are deep-water sandstones whose geometry commonly lends itself to stratigraphic entrapment. Hence, half of all UKCS Palaeogene hydrocarbon discoveries occur in traps with full or partial stratigraphic entrapment (Fig. 8c). Pinch-out traps for instance can occur where Palaeogene sandstones onlap and pinch-out onto the flanks of basin margin or intrabasinal highs (e.g. Everest Field; O’Connor \& Walker 1993). Palaeogeomorphic traps are also developed within both the deep-water and deltaic Palaeogene facies. In these, detached lobes of mass-flow sandstones can exhibit four-way dip closure resulting from a combination of sedimentary mounding and differential post-depositional compaction of the encasing mudstones. Other stratigraphic traps in basin marginal late Palaeocene-early Eocene coastal-deltaic deposits include incised valley fill mounds with compactional drape, sometimes enhanced by delta-top palaeo-relief (Underhill 2001).

Sophisticated seismic techniques appear to work well on Palaeogene reservoirs in the UK North Sea. The trapping mechanism and geometry of the Alba Field, a stratigraphic trap of Eocene age, has been illuminated by 
the use of 3D shearwave volume processing of data collected using sea bottom seismic cables (Jones et al. 2003). The Arbroath and Montrose fields in the UK Central Graben are both simple, four-way dip closures of Palaeocene reservoirs. Seismic attribute analysis has revealed that the primary Forties Sandstone reservoir in both these fields is highly channelized, and AVO techniques have been used successfully to determine the distribution of oil versus water (Ahmadi et al. 2003).

In the West of Shetland area, (Fig. 13), the use of AVO as a hydrocarbon predictor in Palaeogene plays has been less successful. Loizou (2002) determined that of all the wells drilled on prospects with a favourable AVO response, just 19\% succeeded, and all of the successes were also associated with a robust structural closure. Sixty-five percent of recent wells drilled West of Shetland were failures of stratigraphic and combination prospects. To the north-west of the Foinaven Field, for instance, the Assynt prospect was proved dry by well 204/18-1. This prospect had been mapped on the basis of a strong AVO response, interpreted by the well operators to mark the presence of oil within a Palaeocene stratigraphic trap (Loizou 2002). The prospect contained neither an up-dip stratigraphic seal nor fault seals to create a robust trap (Fig. 14). The reason for the AVO response at many failed prospects is poorly understood, but most may be related to changes in lithology (Loizou 2002). There is clearly a need to define future West of Shetland prospects on the basis of a sound geological model and careful structural mapping, in addition to backup from geophysical techniques. The relationship of the potential reservoirs to a good seal is critical. Figure 15 shows a Palaeocene lead within the northern part of the Faroe-Shetland Basin where truncated T32-34 and T35-36 sands occur within a three-way dip closure. Top seal is provided by the Kettla Tuff Member and underlying shales (a regional widespread seal), and lateral seal to the east is stratigraphic, backed up by a fault with good seal potential.

Eocene deep-water sandstones have excellent stratigraphic potential. In the North Sea, the Eocene deep-water sandstone play is well established, with almost all of the fields and discoveries occurring in stratigraphic or combination traps. Amplitude extraction maps have proved a valuable aid to play delineation across the Tay fan play in the Central North Sea (Jones et al. 2003, p. 275, fig. 15.10). Mounded geometries are common within palaeogeomorphic traps (e.g. Frigg and Guillemot fields; Brewster 1991; Jones et al. 2003). Remobilized channel sands provide a locally important Eocene deep-water sandstone play that was brought to light at the discovery of the Alba Field during appraisal drilling on the underlying Britannia Field (Jones et al. 2003). The Alba reservoir proved difficult to distinguish on conventional seismic data, but was clearly resolved using 
multicomponent pressure and shear-wave seismic data acquired through sea-bottom seismic cables (Jones et al. 2003). Such sophisticated techniques are likely to be required for future exploration of this play.

In the West of Shetland area, the Eocene deep-water sandstone fairway covers a substantial part of UK Quadrants 213 and 214 (Fig. 13), but it is only lightly explored. The Eocene fans in this fairway are characterized by high amplitudes on seismic data, mounded topography, and considerable internal complexity (Fig. 16). The lead shown in Figure 16 is a simple four-way dip closure with internal stratigraphic complexity that may enlarge the lead to enhance its hydrocarbon potential.

\section{Summary}

Estimates of the yet-to-find hydrocarbon volumes on the UKCS have been made from both 'bottom-up' and topdown' methods. The DTI's prospect database provides a 'bottom-up' estimate of the yet-to-find resources at end 2002 of 3.6 to $22.9 \times 10^{9}$ BOE recoverable. 'Top-down' methods provide a less optimistic estimate of yet-to-find resources. The pool size distribution method predicts $11.5 \times 10^{9} \mathrm{BOE}$ of in-place resources (c. $5.8 \times 10^{9} \mathrm{BOE}$ recoverable), and the inverse discovery curve method suggests that the yet-to-find resources are between 4.5 and $9.5 \times 10^{9} \mathrm{BOE}$ in place (2.1 to $4.4 \times 10^{9} \mathrm{BOE}$ recoverable). The discovery curve for the entire UKCS shows a maturing signature, whilst discovery curves for individual plays or smaller geographic areas provide evidence for resurgence. Both the DTI's prospect database and the discovery curve data suggest that the Central North Sea has the greatest yet-to-find resource. Exploration success expressed as a percentage of discoveries per exploration well is $31.1 \%$ for the period 1964 to 2002. Despite low levels of exploration, recent years have yielded even higher success levels, with an all time high in 1999 of 56.3\%, and an average for 1999-2002 of $50 \%$. This is a testament to more focused exploration through increased use of sophisticated technologies and more rigorous prospect risking, and it gives optimism that there will be many future exploration successes.

Stratigraphic traps account for only 5\% of existing UKCS fields and discoveries, but they have been the targets of relatively few wells up to now. Several fields in stratigraphic traps were discovered serendipitously during drilling of deeper structural targets. The spectacular discovery of the Buzzard Field in 2001 has marked the beginning of a new era of active exploration for stratigraphic traps. Of the forecast 3.6 to $22.9 \times 10^{9} \mathrm{BOE}$ recoverable UKCS yet-to-find, it is estimated that $55 \%$ is located within stratigraphic traps. 
Stratigraphic traps are most important within Upper Jurassic syn-rift and Cretaceous to Palaeogene post-rift plays. Deep-water sandstones with limited lateral distribution constitute the principal reservoir in these plays. Successful exploration for such targets will rely on:

- well-grounded conceptual models for reservoir distribution enabling robust prediction of trap configuration

- well-constrained use of seismic techniques such as AVO analysis and long offset seismic where appropriate to map trap geometry and pinpoint drilling locations.

\section{Acknowledgements}

This paper is published with the permission of the Director of Licensing and Consents Unit, Department of Trade and Industry, and the Executive Director, British Geological Survey (NERC). We gratefully acknowledge permission to publish seismic data owned by Fugro-Geoteam AS, PGS Geophysical and Western-Geco. EnCana are thanked for permission to publish our lead interpretation across their licensed acreage.

\section{References}

Ahmadi, Z. M., Sawyers, M., Kenyon-Roberts, S., Stanworth, C. W., Kugler, K. A., Kristensen, J. \& Fugelli, E. M. G. 2003. Paleocene. In: Evans, D., Graham, C., Armour, A. and Bathurst, P. (editors and coordinators) The Millennium Atlas: petroleum geology of the central and northern North Sea. Geological Society, London, 235259.

Brewster, J. 1991. The Frigg Field, Block 10/1 UK North Sea and 25/1, Norwegian North Sea. In: Abbotts, I. L. (ed.) United Kingdom Oil and Gas Fields, 25 Years Commemorative Volume, Geological Society, London, Memoirs, 14, 117-126.

Cameron, T. D. J., Munns, J. W. \& Stoker, S. J. In press. Remaining exploration potential of the Carboniferous fairway, UK Southern North Sea. In: Hydrocarbon resources of the Carboniferous, Southern North Sea and surrounding onshore areas. Yorkshire Geological Society Special Publication. 
Copestake, P., Sims, A. P., Crittenden, S., Hamar, G. P., Ineson, J. R., Rose, P. T. \& Tringham, M. E. 2003. Lower Cretaceous. In: Evans, D., Graham, C., Armour, A. \& Bathurst, P. (editors and coordinators) The Millennium Atlas: petroleum geology of the central and northern North Sea. Geological Society, London, 191211.

Coward, R. N., Clark, N. M. \& Pinnock, S. J. 1991. The Tartan Field, Block 15/16, UK North Sea. In: Abbotts, I. L. (ed.) United Kingdom Oil and Gas Fields, 25 Years Commemorative Volume, Geological Society, London, Memoirs, 14, 377-384.

Department of Trade and Industry. 2002. Promote United Kingdom 2003: Petroleum potential of the United Kingdom Continental Shelf. CD-ROM.

Department of Trade and Industry. 2003. Department of Trade and Industry Oil and Gas Information. World Wide Web Address: http://www.og.dti.gov.uk/information/index.htm.

Doré, G. \& Robbins, J. 2004. The Buzzard Field. In: Doré, A. G. \& Vining, B. (eds) Petroleum Geology: NorthWest Europe and Global Perspectives - Proceedings of the 6th Petroleum Geology Conference. Geological Society, London, $\mathrm{xxx}-\mathrm{xxx}$.

Garrett, S. W., Atherton, T. \& Hurst, A. 2000. Lower Cretaceous deep-water sandstone reservoirs of the UK Central North Sea. Petroleum Geoscience, 6, 231-240.

Johnson, H. D. \& Fisher, M. J. 1998. North Sea plays: geological controls on hydrocarbon distribution. In: Glennie, K. W. (editor) Petroleum geology of the North Sea, basic concepts and recent advances (fourth edition). Oxford: Blackwell Scientific Publications, 463-547.

Jones, E., Jones, R., Ebdon, C., Ewen, D., Milner, P., Plunkett, J., Hudson, G. \& Slater, G. 2003. Eocene. In: Evans, D., Graham, C., Armour, A. \& Bathurst, P. (editors and coordinators) The Millennium Atlas: petroleum geology of the central and northern North Sea. Geological Society, London, 261-277. 
Ketter, F. J. 1991. The Ravenspurn North Field, Blocks 42/30, 43/26a, UK North Sea. In: Abbotts, I. L. (ed.) United Kingdom Oil and Gas Fields, 25 Years Commemorative Volume, Geological Society, London, Memoirs, 14, 459-467.

Law, A., Raymond, A., White, G., Atkinson, A., Clifton, M., Atherton, T., Dawes, I., Robertson, E., Melvin, A., \& Brayley, S. 2000. The Kopervik fairway, Moray Firth, UK. Petroleum Geoscience, 6, 265-274.

Loizou, N. 2002. A post-well analysis of recent years exploration drilling in the Atlantic Margin. SHARP IOR eNewsletter, Issue 3, http://ior.rml.co.uk.

McGann, G. J., Green, S. C. H., Harker, S. D. \& Romani, R. S. 1991. The Scapa Field, Block 14/19, UK North Sea. In: Abbotts, I. L. (ed.) United Kingdom Oil and Gas Fields, 25 Years Commemorative Volume, Geological Society, London, Memoirs, 14, 369-376.

Megson, J. \& Hardman, R. 2001. Exploration for and development of hydrocarbons in the Chalk of the North Sea: a low permeability system. Petroleum Geoscience, 7, 3-12.

Morgan, R., Toothill, A. \& Fogg, A. 2002. What remains to be found in the Central Graben, North Sea? A role for long(er) offset seismic data. Extended abstracts, PETEX 2002 CD-ROM.

O’Connor, S. J. \& Walker, D. 1993. Palaeocene reservoirs of the Everest trend. In: Parker, J. R. (ed.) Petroleum Geology of Northwest Europe: Proceedings of the $4^{\text {th }}$ Conference, Geological Society, London, 145-160.

PILOT Taskforce. 2001. Study produced evidence of unexploited North Sea resources existing field may yield 4 billion more barrels of oil than expected. PILOT Briefing No 7 (November 2001).

Roberts, M. J. 1991. The South Brae Field, Block 16/7a, UK North Sea. In: Abbotts, I. L. (ed.) United Kingdom Oil and Gas Fields, 25 Years Commemorative Volume, Geological Society, London, Memoirs, 14, 55-62. 
Schmitt, H. R. \& Gordon, A. F. 1991. The Piper Field, Block 15/17, UK North Sea. In: Abbotts, I. L. (ed.)

United Kingdom Oil and Gas Fields, 25 Years Commemorative Volume, Geological Society, London, Memoirs, 14, 361-368.

Stockbridge, C. P. \& Gray, D. I. 1991 The Fulmar Field, Blocks 30/16 and 30/11b, UK North Sea. In: Abbotts, I. L. (ed.) United Kingdom Oil and Gas Fields, 25 Years Commemorative Volume, Geological Society, London, Memoirs, 14, 309-316.

Trewin, N. H. \& Bramwell, M. G. 1991. The Auk Field, Block 30/16, UK North Sea. In: Abbotts, I. L. (ed.) United Kingdom Oil and Gas Fields, 25 Years Commemorative Volume, Geological Society, London, Memoirs, 14, 55-62.

Underhill, J. R. 2001. Controls on the genesis and prospectivity of Palaeogene palaeogeomorphic traps, East Shetland Platform, UK North Sea. Marine and Petroleum Geology, 18, 259-281.

United Kingdom Offshore Operators Association. 2003. UKCS exploration activity survey report. World Wide Web Address: http://www.oilandgas.org.uk/issues/sustainability/introduction.htm.

United States Geological Survey. 1995. A new approach to estimating hydrocarbon resources. U. S. Geological Survey Energy Resource Surveys Program Fact Sheet, January 1995. World Wide Web Address: http://www.energy.usgs.gov/factsheets/HydroRes/estimat.html.

Whitehead, M. \& Pinnock, S. J. 1991. The Highlander Field, Block 14/20b, UK North Sea. In: Abbotts, I. L. (ed.) United Kingdom Oil and Gas Fields, 25 Years Commemorative Volume, Geological Society, London, Memoirs, 14, 323-329. 
Table 1. Estimates of undiscovered recoverable resources in the UK at the end of 2002 (from DTI 2003).

Table 2. Breakdown of UK undiscovered recoverable resources by geographic area.

Table 3. Breakdown of UKCS known and undiscovered resources by play.

Fig. 1. Major basins of the United Kingdom Continental Shelf.

Fig. 2. Discovery curve and discovery history histogram for UKCS fields and discoveries.

Fig. 3. (a) UKCS drilling success rate (percentage of offshore exploration wells that have proved technical successes, as included in the DTI's field and PARs databases) (data from DTI sources). (b) Number of exploration wells drilled on the UKCS per year.

Fig. 4. Discovery curves and discovery history histograms for (a) Northern North Sea, (b) Central North Sea (including Moray Firth), (c) Southern North Sea, (d) West of Shetland, (e) Middle Jurassic shallow marine/deltaic sandstone play (including Brent Province), (f) Palaeogene deep-water sandstone play, (g) Lower Cretaceous deep-water sandstone play, (h) Upper Jurassic deep-water sandstone play.

Fig. 5. Estimation of UKCS yet-to-find from discovery curve data.

Fig. 6. Estimation of UKCS yet-to-find from field size distribution data derived from known fields and discoveries.

Fig. 7. Distribution of UKCS yet-to-find by play.

Fig. 8. Importance of stratigraphic and combination traps in UKCS fields and discoveries. (a) Proportion of 679 UKCS fields and discoveries in structural, stratigraphic and combination traps (b) proportion of UKCS resources 
in structural, stratigraphic and combination traps (c) summary of gross pre-, syn- and post-rift plays and the relative importance of structural, stratigraphic and combination traps in each play.

Fig. 9. (a) Geoseismic section showing Carboniferous erosional truncation combination traps in Southern North Sea Quadrants 43 and 44. Intraformational sealing is critical where structural closure is absent at base Permian level. (b) Ketch Member (Westphalian C-D red beds) sub-fairway in Southern North Sea (after Cameron et al. in press).

Fig. 10. Schematic diagram illustrating a mechanism for development of combination traps in the Lower Permian Rotliegend Group in the Southern Gas Basin. Shales and evaporates of the Lower Permian Silverpit Formation will provide lateral and top seals to the aeolian sands at their pinch-out limit.

Fig. 11. Late Jurassic syn-rift stratigraphic plays. (a) Location map (b) Example of stratigraphic trap: potential deep-water sands pinch-out trap is implied by amplitude anomaly within wedging unit of Kimmeridgian age (after DTI 2002) (c) Example of combination trap: potential deep-water sand unit exhibits marked updip pinchout to the west and fault closure to the south.

Fig. 12. Occurrence of sands within Lower Cretaceous well sections in UK Quadrants 29 and 30, and speculative distribution of Late Ryazanian to Valanginian deep-water sands.

Fig. 13. Distribution of Palaeogene deep-water sandstone plays, West of Shetland.

Fig. 14. Geoseismic section across successful (Foinaven Field) and failed (Assynt well) Palaeocene deep-water sandstone targets. See Fig. 13 for location of section.

Fig. 15 Example of Palaeocene combination trap within gas-prone part of the Faroe-Shetland Basin. Truncation of T32-36 sands beneath the regional seal provides stratigraphic entrapment to the east within a 3-way dip closure. Onlapping of intra-Palaeocene horizons suggests the potential for additional leads. See Fig. 13 for location of section. 
Munns J.W., Gray J.C., Stoker S.J., Andrews I.J. \& Cameron T.D.J.

Fig. 16 Mid-Eocene deep-water sandstone lead: complex mounded fan interval lies within a broad anticline (after DTI 2002). See Fig. 13 for location of section. 
Munns J.W., Gray J.C., Stoker S.J., Andrews I.J. \& Cameron T.D.J.

Table 1. Estimates of undiscovered recoverable resources in the UK at the end of 2002 (from DTI 2003)

\begin{tabular}{|c|c|c|c|c|c|c|}
\hline & \multicolumn{2}{|c|}{ Oil } & \multicolumn{3}{|c|}{ Gas } & \multirow{2}{*}{$\begin{array}{r}\text { Total } \\
\times 10^{9} \mathrm{BOE}\end{array}$} \\
\hline & $\begin{array}{c}\mathrm{x} 10^{6} \\
\text { tonnes }\end{array}$ & $\begin{array}{l}\times 10^{9} \\
\text { BBL }\end{array}$ & $\begin{array}{r}\times 10^{9} \text { cubic } \\
\text { metres }\end{array}$ & $\begin{array}{r}\times 10^{9} \\
\text { cubic feet }\end{array}$ & $\mathrm{x} 10^{9} \mathrm{BOE}$ & \\
\hline $\begin{array}{l}\text { Lower } \\
\text { (P90) }\end{array}$ & 270 & 2.025 & 235 & 8,298 & 1.622 & 3.6 \\
\hline $\begin{array}{l}\text { Central } \\
\text { (P50) }\end{array}$ & 705 & 5.288 & 532 & 18,785 & 3.671 & 9.0 \\
\hline $\begin{array}{l}\text { Upper } \\
\text { (P10) }\end{array}$ & 1770 & 13.275 & 1390 & 49,081 & 9.591 & 22.9 \\
\hline
\end{tabular}

[conversions used: 1 tonne crude oil $=7.5$ barrels; 1 cubic metre $=35.31$ cubic feet; $1 \times 10^{9}$ cubic metres of gas $=6.9 \times 10^{6} \mathrm{BOE}$ based on calorific values] 
Munns J.W., Gray J.C., Stoker S.J., Andrews I.J. \& Cameron T.D.J.

Table 2. Breakdown of UK undiscovered recoverable resources by geographic area

\begin{tabular}{lcc}
\hline & $\begin{array}{l}\text { Percentage of estimated } \\
\text { undiscovered recoverable } \\
\text { resources (central figure/P50) } \\
\text { (Department of Trade and } \\
\text { Industry 2003) }\end{array}$ & $\begin{array}{l}\text { Percentage of estimated } \\
\text { undiscovered recoverable } \\
\text { resources (United Kingdom } \\
\text { Offshore Operators } \\
\text { Association 2003) }\end{array}$ \\
\hline Northern North Sea (north of 59 $\mathrm{N})$ & 8 & 10 \\
Central North Sea and Moray Firth & 42 & 50 \\
Atlantic Margin & 33 & 11 \\
Southern North Sea & 11 & 14 \\
East Irish Sea & 5 & $14 *$ \\
Land & 1 & - \\
\hline
\end{tabular}

* = West of England and Wales, Irish Sea and English Channel 
Table 3. Breakdown of UKCS known and undiscovered resources by play

\begin{tabular}{|c|c|c|c|c|c|}
\hline & Play group * & $\begin{array}{r}\text { Estimate of total } \\
\text { hydrocarbon } \\
\text { resource at end } \\
2002\left(\times 10^{6} \mathrm{BOE}\right. \\
\text { initially in place }) \dagger\end{array}$ & $\%$ & $\begin{array}{r}\text { Estimated } \\
\text { percentage of total } \\
\text { yet-to-find at end } \\
2002 \text { in each play } \\
\text { group }\end{array}$ & $\begin{array}{r}\text { Estimated } \\
\text { percentage of total } \\
\text { yet-to-find in } \\
\text { stratigraphic and } \\
\text { combination traps }\end{array}$ \\
\hline \multirow{5}{*}{ POST-RIFT } & Pliocene sandstones & 23 & $<0.1$ & 0 & \\
\hline & $\begin{array}{l}\text { Palaeogene deltaic } \\
\text { sandstones }\end{array}$ & 1,901 & 1.8 & 2 & \\
\hline & $\begin{array}{l}\text { Palaeogene deep- } \\
\text { water sandstones }\end{array}$ & 21,703 & 21.0 & 22 & 33 \\
\hline & $\begin{array}{l}\text { Upper Cretaceous } \\
\text { carbonates }\end{array}$ & 2,183 & 2.1 & 5 & \\
\hline & $\begin{array}{l}\text { Lower Cretaceous } \\
\text { deep-water sandstones }\end{array}$ & 3,163 & 3.1 & 12 & \\
\hline \multirow[b]{2}{*}{ SYN-RIFT } & $\begin{array}{l}\text { Upper Jurassic deep- } \\
\text { water sandstones }\end{array}$ & 8,585 & 8.3 & 22 & \\
\hline & $\begin{array}{l}\text { Upper Jurassic } \\
\text { shallow } \\
\text { marine/deltaic } \\
\text { sandstones }\end{array}$ & 12,281 & 11.9 & 8 & 17 \\
\hline \multirow{9}{*}{ PRE-RIFT } & $\begin{array}{l}\text { Middle Jurassic } \\
\text { shallow } \\
\text { marine/deltaic } \\
\text { sandstones }\end{array}$ & 26,825 & 25.9 & 3 & \\
\hline & $\begin{array}{l}\text { Upper Triassic to } \\
\text { Lower Jurassic } \\
\text { sandstones }\end{array}$ & 3,269 & 3.2 & 8 & \\
\hline & $\begin{array}{l}\text { Lower Triassic fluvial } \\
\text { sandstones }\end{array}$ & 3,593 & 3.5 & 1 & \\
\hline & $\begin{array}{l}\text { Permian aeolian } \\
\text { sandstones }\end{array}$ & 11,799 & 11.4 & 7 & 5 \\
\hline & Permian carbonates & 985 & 1.0 & 1 & \\
\hline & $\begin{array}{l}\text { Carboniferous } \\
\text { sandstones }\end{array}$ & 6,625 & 6.4 & 8 & \\
\hline & Devonian sandstones & 627 & 0.6 & 1 & \\
\hline & Basement & 6 & $<0.1$ & 0 & \\
\hline & Total & 103,568 & & & 55 \\
\hline
\end{tabular}

* Play groups are condensed from a list of 43 UKCS plays

$\dagger$ All discovered resources and PARs are included 


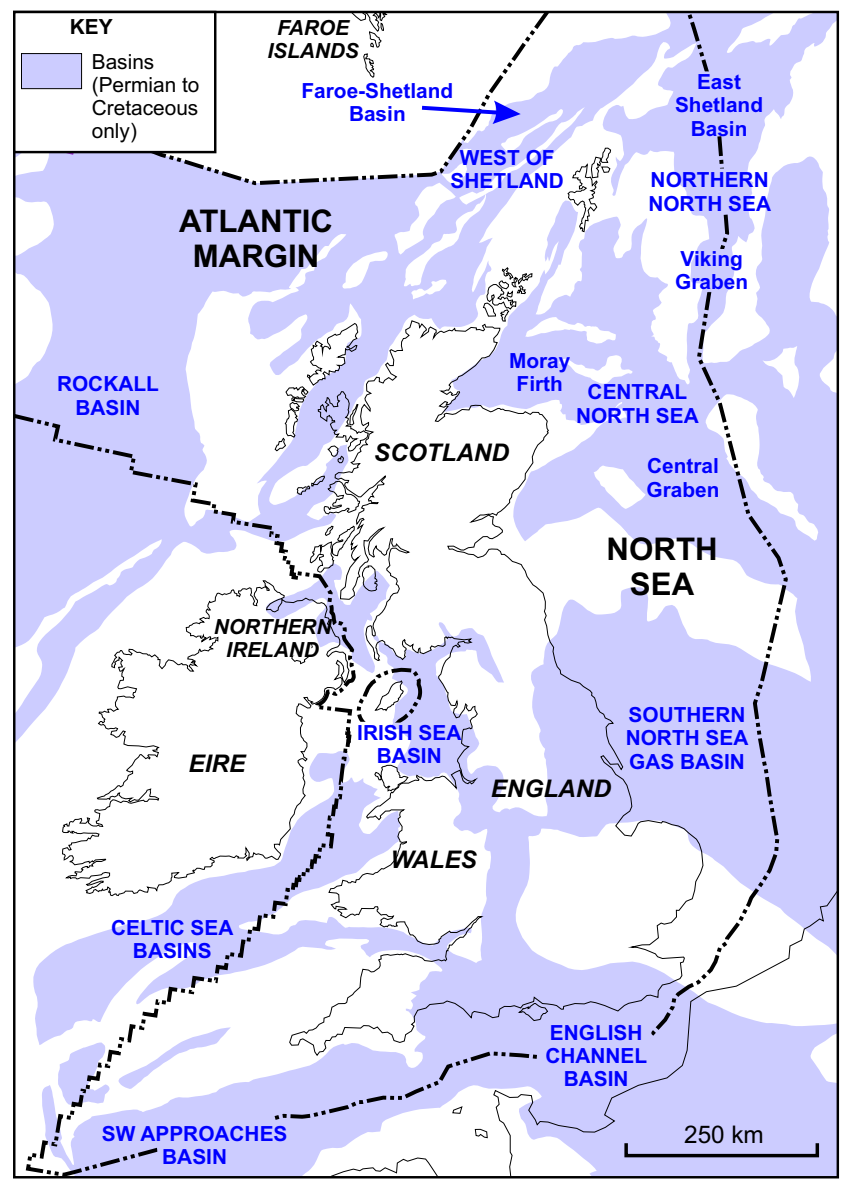




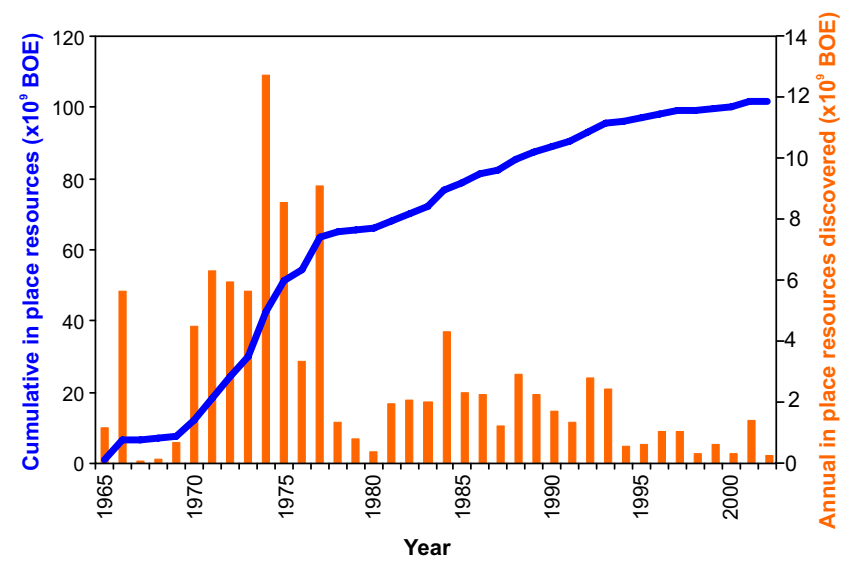



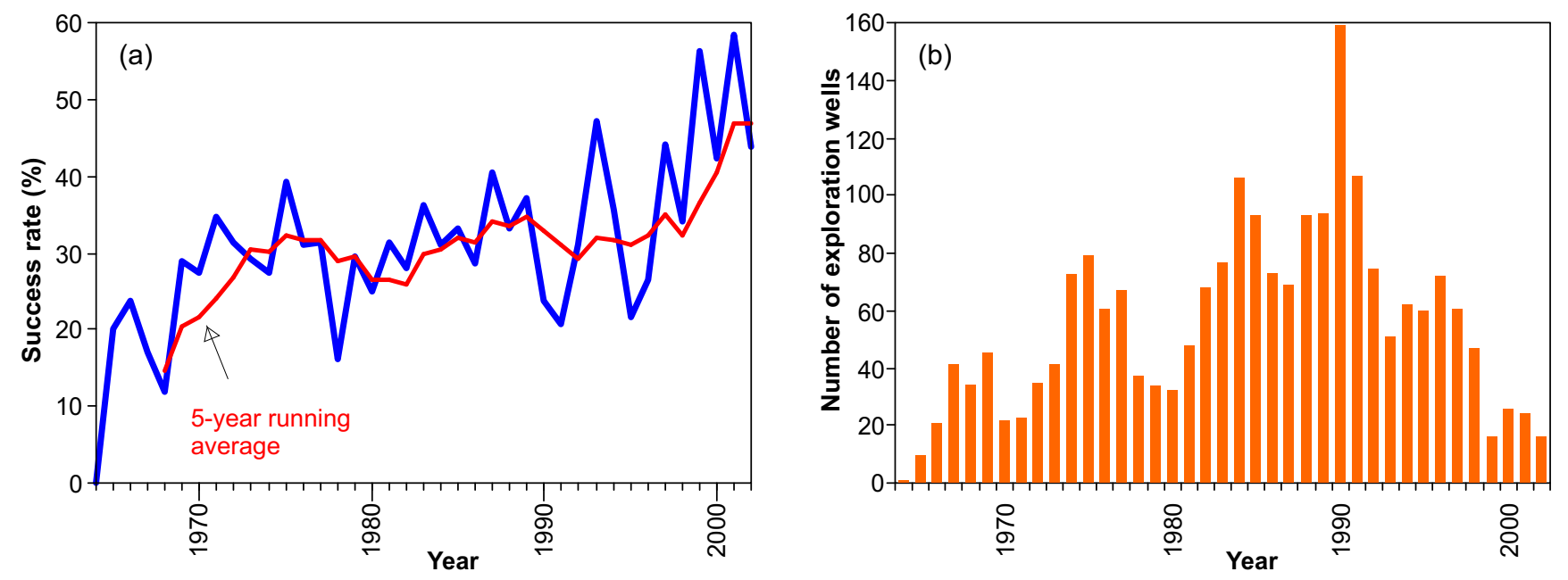

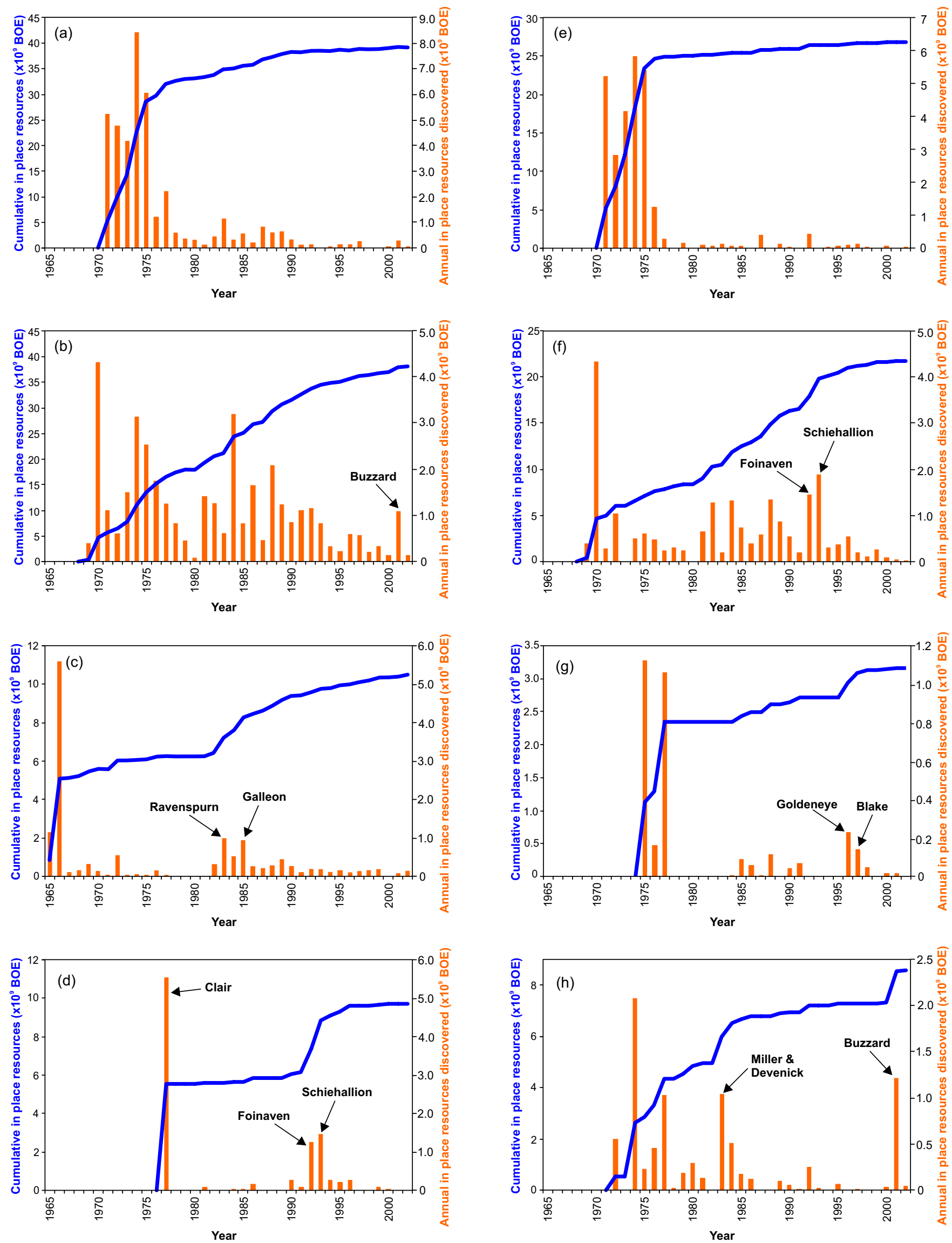


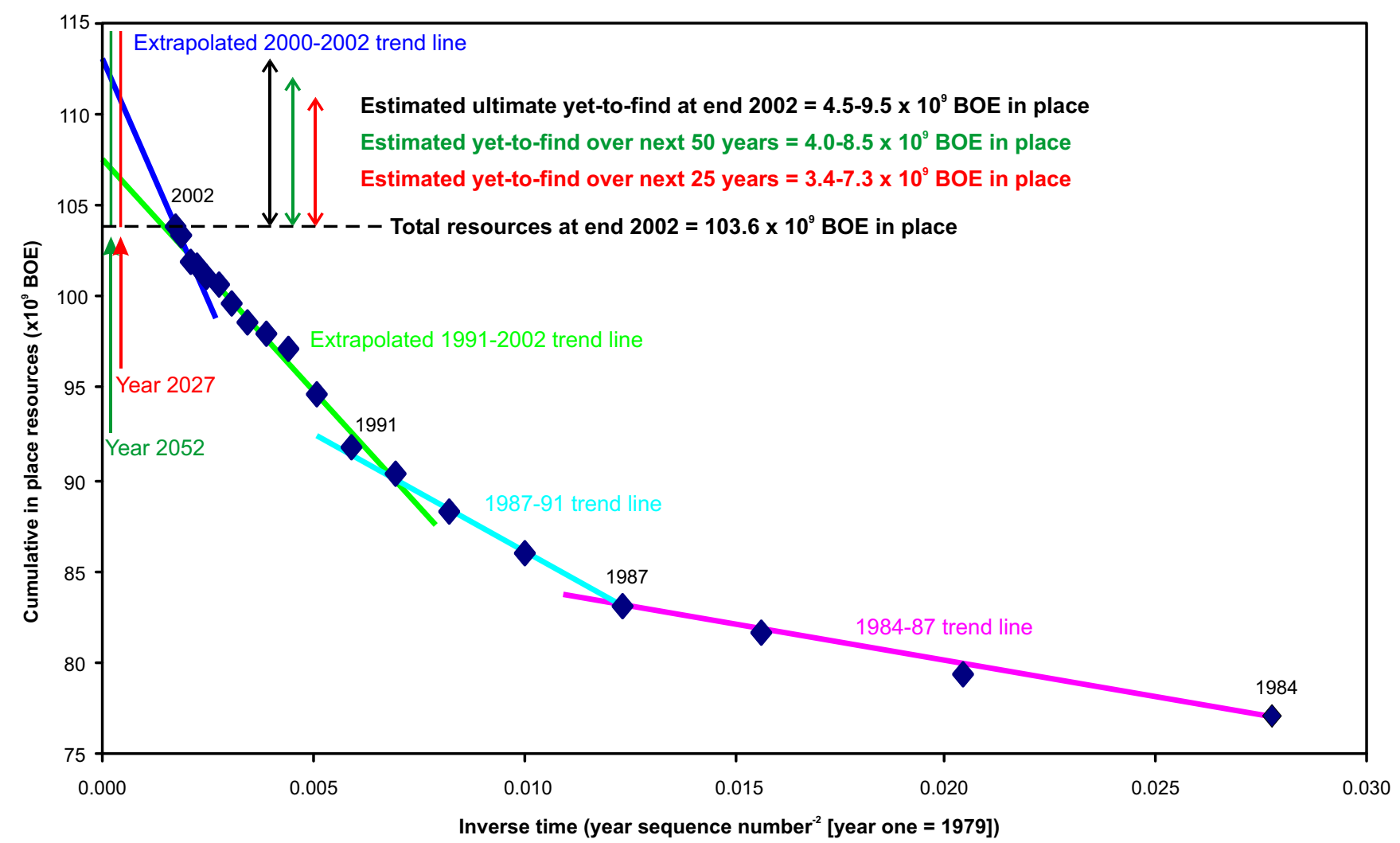




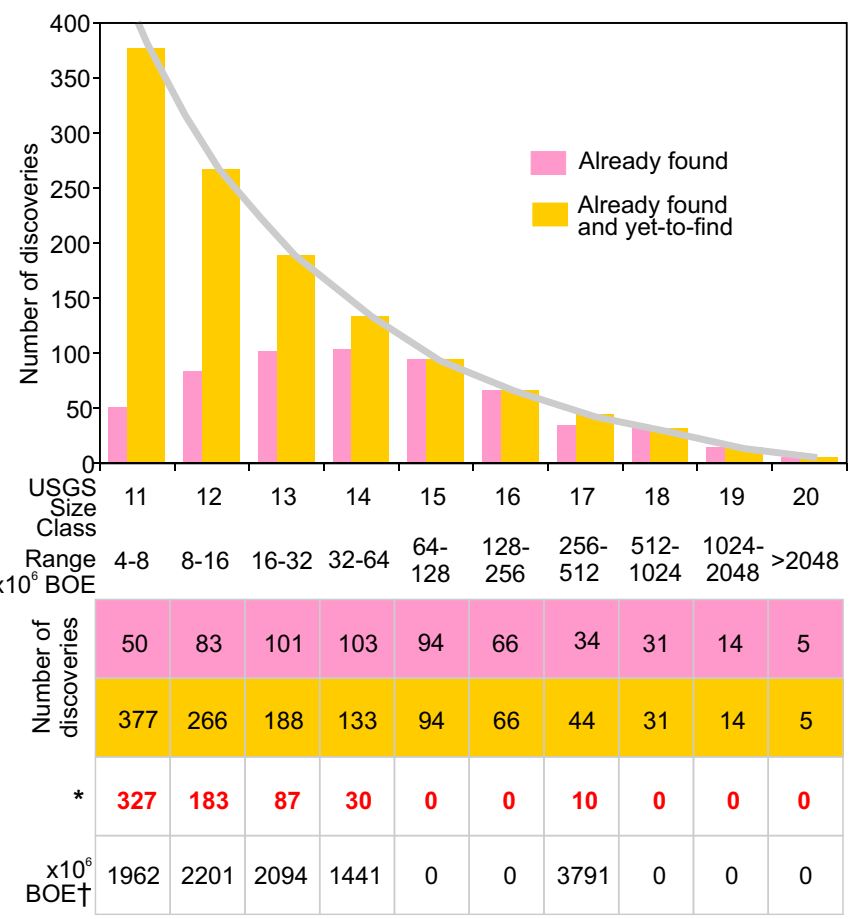

* Predicted number of discoveries still to find in each USGS size class † Estimated yet-to-find in each USGS size class based on average of size class. Total for USGS size classes $11-20=11.5 \times 10^{9} \mathrm{BOE}$ 


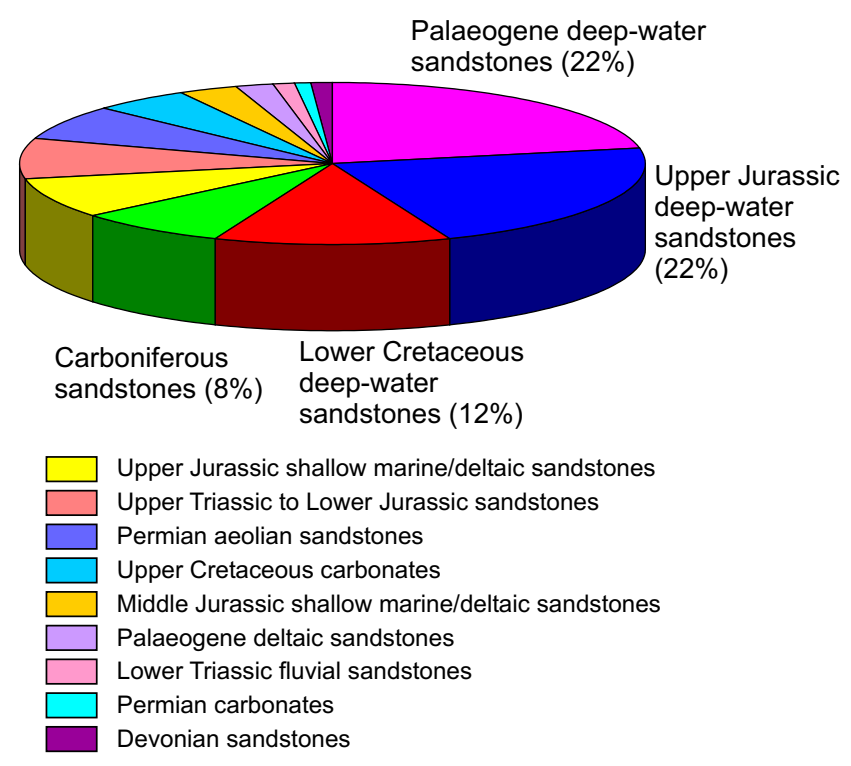


(a)

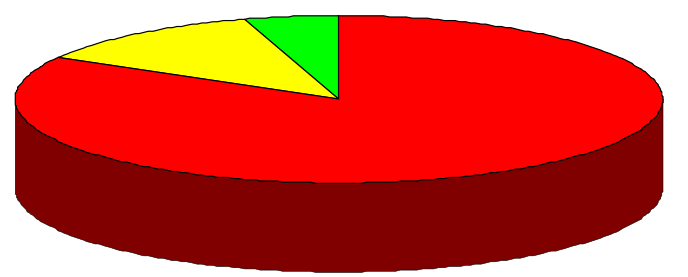

Key to trap type

Structural traps

Combination traps

Stratigraphic traps (b)

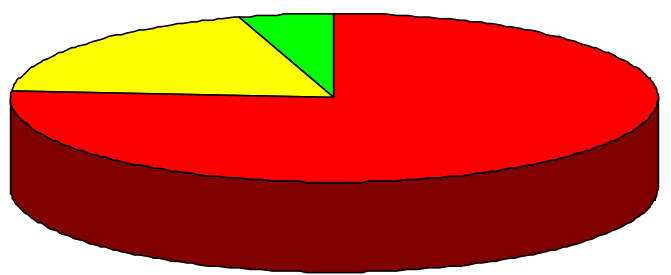

(c)

\begin{tabular}{|c|c|c|c|c|}
\hline \multicolumn{2}{|c|}{ Gross play } & \multirow[b]{2}{*}{$\begin{array}{l}\text { Trap types within play } \\
\text { Structural: drape across fault blocks and salt } \\
\text { structures. } \\
\text { Stratigraphic: detached basin-floor channel and } \\
\text { fan mounds. } \\
\text { Combination: combined dip and stratigraphic } \\
\text { pinch-out traps, combined palaeogeomorphic } \\
\text { and basement drape traps. }\end{array}$} & \multirow[b]{2}{*}{$\begin{array}{l}\text { UKCS examples } \\
\text { Structural: e.g. Forties, } \\
\text { Montrose, Andrew, Machar, } \\
\text { Foinaven } \\
\text { Combination: e.g. East } \\
\text { Foinaven, Gannet F, } \\
\text { Schiehallion } \\
\text { Stratigraphic: e.g. Alba, Frigg, } \\
\text { Everest, Gryphon, Harding, } \\
\text { Pilot }\end{array}$} & \multirow[t]{2}{*}{ Fields and discoveries per trap } \\
\hline \multirow[b]{2}{*}{$\begin{array}{l}\frac{1}{2} \\
\frac{1}{1} \\
0 \\
0 \\
0\end{array}$} & Palaeogene & & & \\
\hline & $\begin{array}{l}\text { Upper } \\
\text { Cretaceous }\end{array}$ & $\begin{array}{l}\text { Existing UKCS fields and discoveries are } \\
\text { located mainly within structural traps. However, } \\
\text { an increasing number of traps have been shown } \\
\text { to include a component of stratigraphic } \\
\text { entrapment by low porosity reservoir units } \\
\text { following post-charge trap tilting. The Halfdan } \\
\text { Field (Danish sector) is entirely stratigraphic. }\end{array}$ & $\begin{array}{l}\text { Structural: e.g. Kyle, Banff, } \\
\text { Orion } \\
\text { Combination: e.g. Joanne, } \\
\text { Fife, Flora }\end{array}$ & \\
\hline$\sum_{\infty}^{\frac{4}{2}}$ & $\begin{array}{l}\text { Upper } \\
\text { Jurassic }\end{array}$ & $\begin{array}{l}\text { Trap type is highly variable. Many of the } \\
\text { combination traps found were initially identified } \\
\text { as structural traps (e.g. Brae fields). Deep-water } \\
\text { sandstone reservoirs commonly have an } \\
\text { element of stratigraphic trapping; shallow- } \\
\text { marine syn-rift sandstones mainly occur in } \\
\text { structural traps. }\end{array}$ & $\begin{array}{l}\text { Structural: e.g. Durward, East } \\
\text { Brae, Janice, Piper, Renee, } \\
\text { Solan, Telford } \\
\text { Combination: e.g. Kittiwake, } \\
\text { Magnus, South, Central \& } \\
\text { North Brae } \\
\text { Stratigraphic: e.g. Miller, } \\
\text { Dauntless, Tartan, } \\
\text { Highlander } \\
\end{array}$ & \\
\hline \multirow{3}{*}{ 흔 } & $\begin{array}{l}\text { Middle } \\
\text { Jurassic }\end{array}$ & $\begin{array}{l}\text { Structural trap types predominate. Simple and } \\
\text { complex tilted or horst fault block traps; crestal } \\
\text { slumping and degradation is common in the } \\
\text { Brent province (East Shetland Basin). } \\
\text { Successful hanging-wall traps are relatively } \\
\text { uncommon. }\end{array}$ & $\begin{array}{l}\text { Structural: e.g. Beatrice, } \\
\text { Beinn, Brent, Ninian, } \\
\text { Seagull } \\
\text { Combination: e.g. Beryl }\end{array}$ & \\
\hline & $\begin{array}{l}\text { Triassic - } \\
\text { Lower } \\
\text { Jurassic }\end{array}$ & $\begin{array}{l}\text { Structural trap types predominate. Simple and } \\
\text { complex tilted horst fault block traps; successful } \\
\text { hanging-wall traps are relatively rare. } \\
\text { Commonly found stacked in the same trap with } \\
\text { overlying Middle Jurassic reservoirs. Triassic } \\
\text { (Skagerrak Formation) reservoirs in Central } \\
\text { North Sea occur in salt-controlled mini-basins or } \\
\text { pods. }\end{array}$ & $\begin{array}{l}\text { Structural: e.g.Beryl, Esmond, } \\
\text { Hewett, Judy, Marnock, } \\
\text { Morecambe, Statfjord } \\
\text { Combination: e.g. Kittiwake, } \\
\text { Strathmore }\end{array}$ & \\
\hline & Palaeozoic & $\begin{array}{l}\text { Almost entirely structural traps found. } \\
\text { Reservoirs range from fractured basement } \\
\text { rocks, through Devonian, Carboniferous and } \\
\text { Permian strata. }\end{array}$ & $\begin{array}{l}\text { Structural: e.g. Argyll, Buchan, } \\
\text { Clair, Innes, Leman, } \\
\text { Murdoch } \\
\text { Combination: e.g. Auk, Tyne } \\
\text { complex, Murdoch K (CMS- } \\
\text { III), Ravenspurn North }\end{array}$ & \\
\hline
\end{tabular}


NE

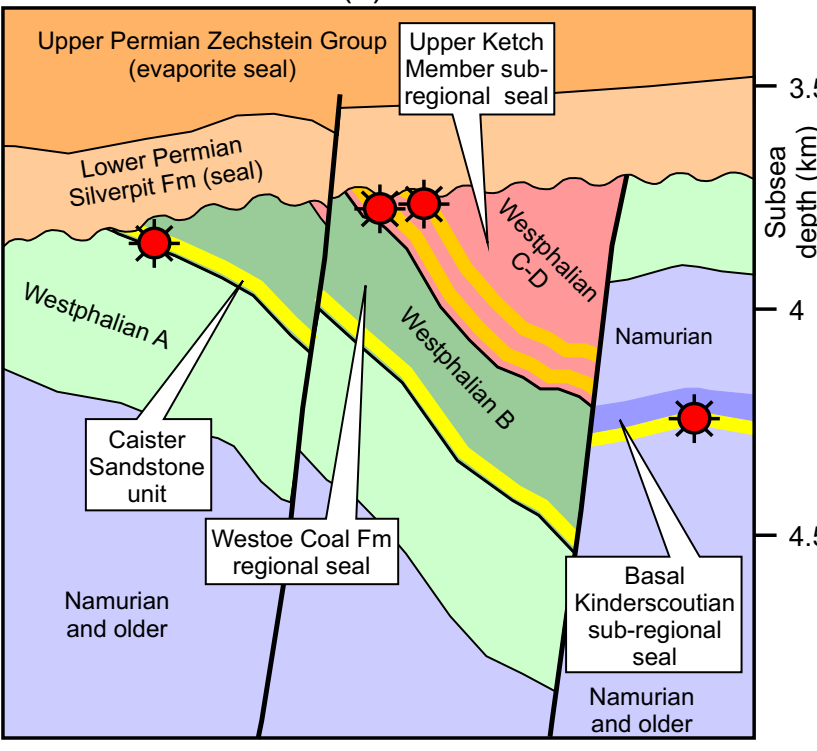

(b)

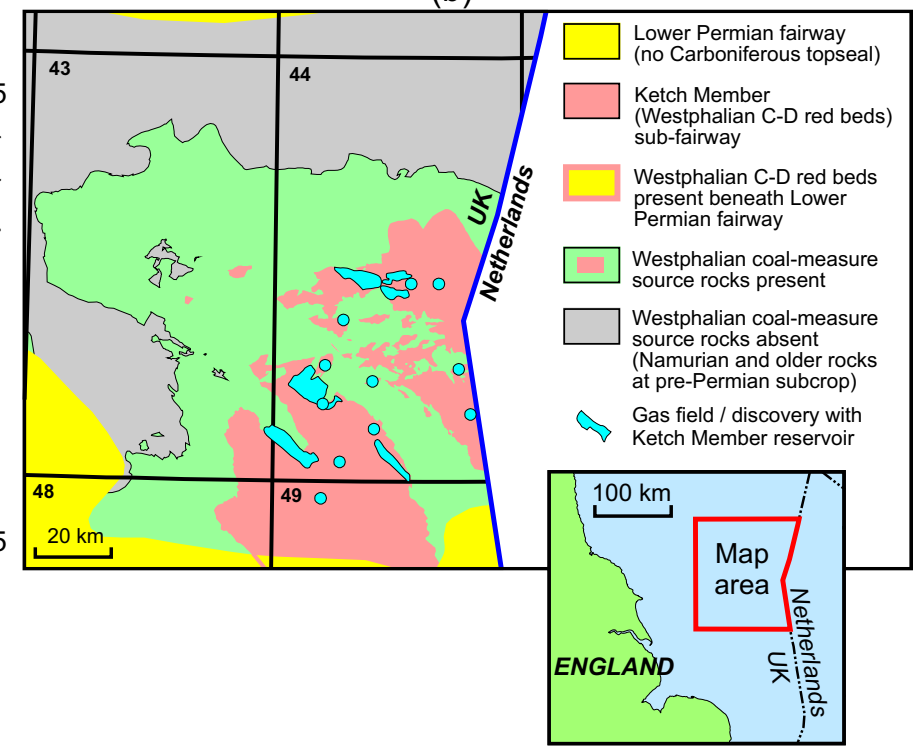




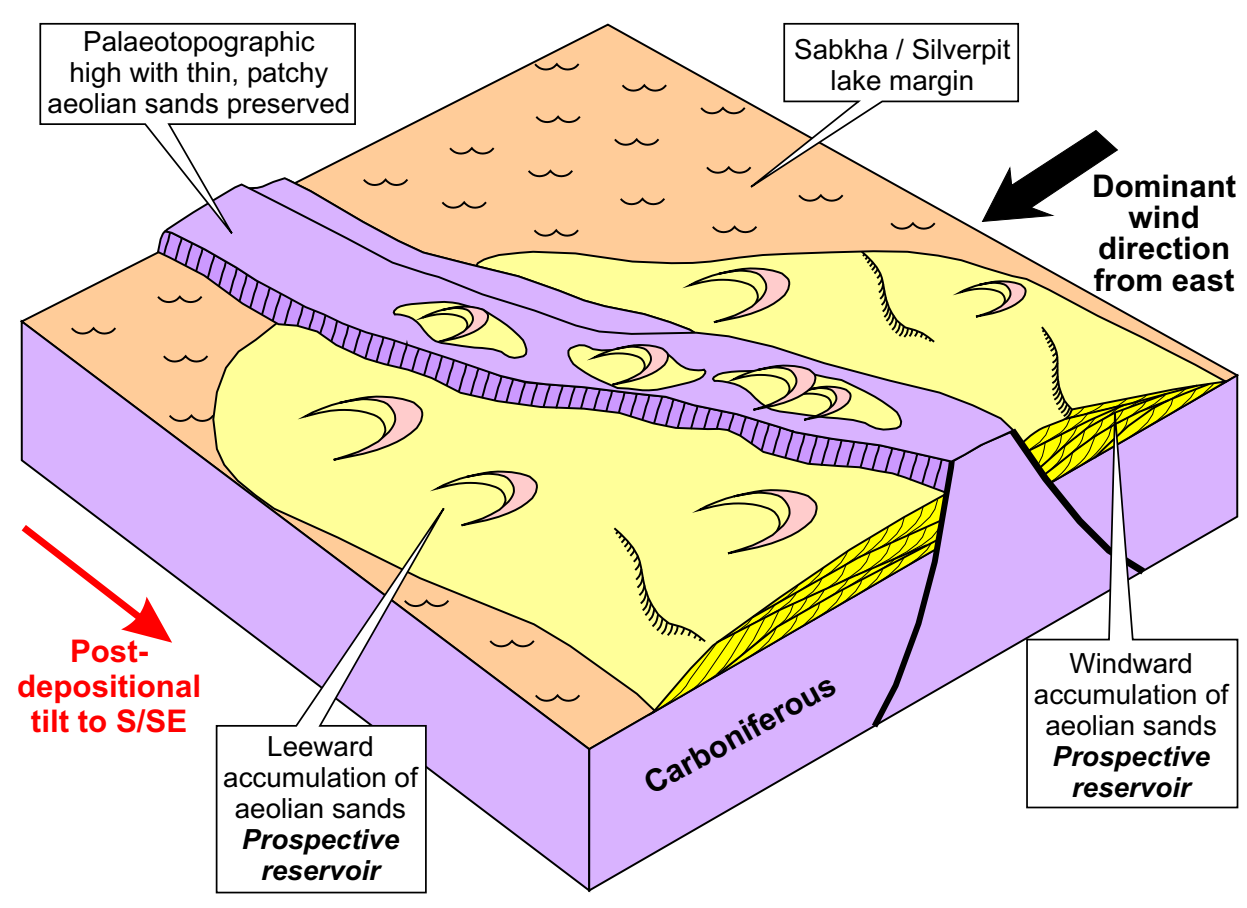




\section{A}

(b)

$\mathbf{A}^{1}$

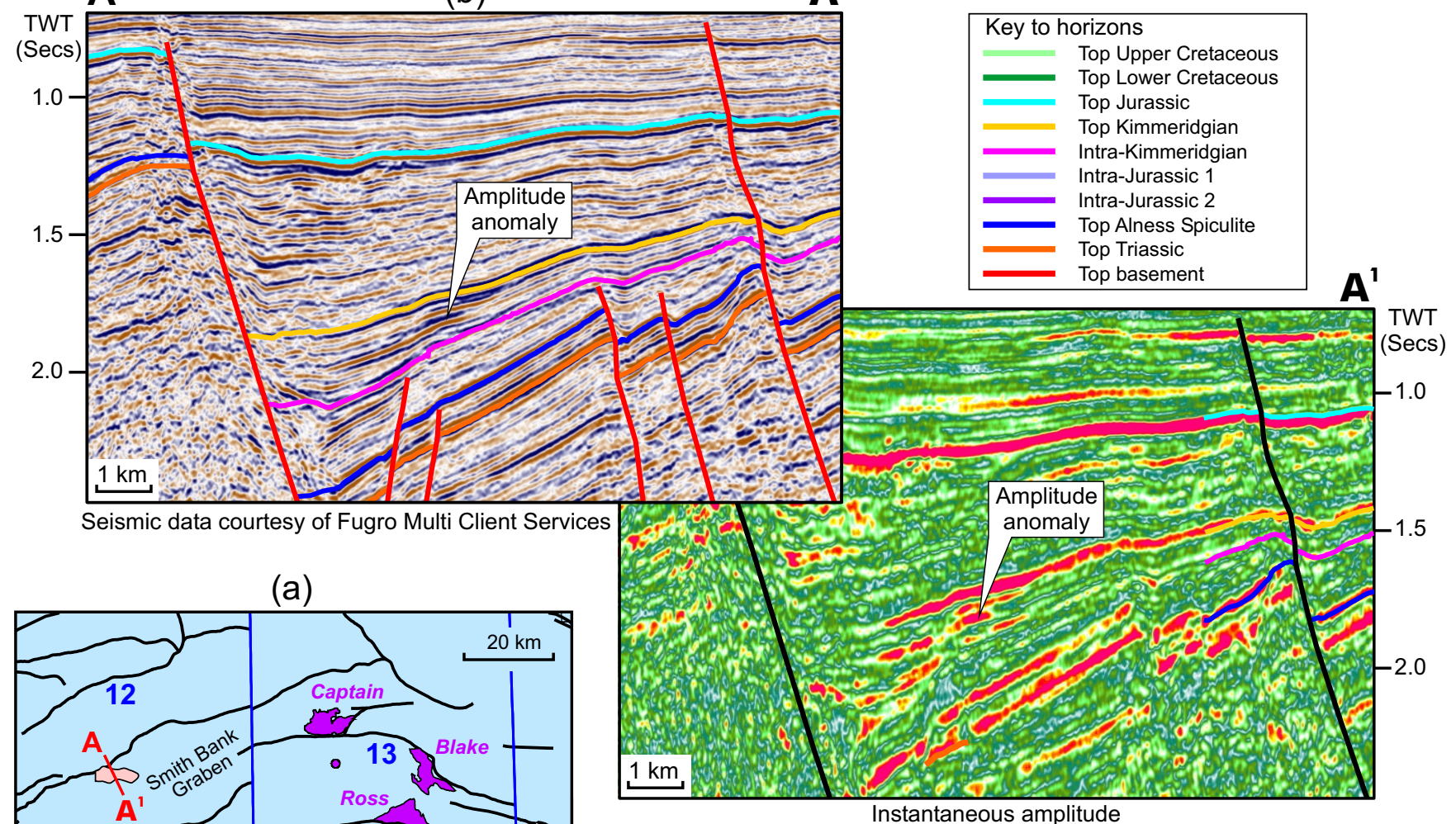

○

A
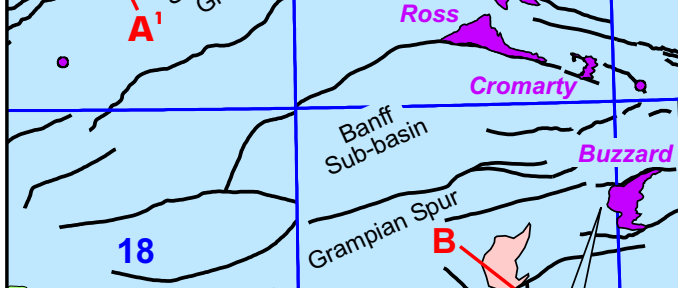

sub-b
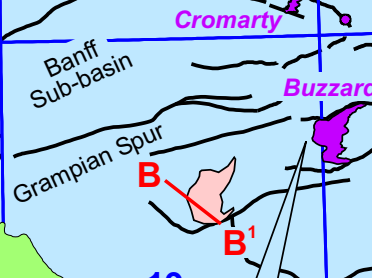

19

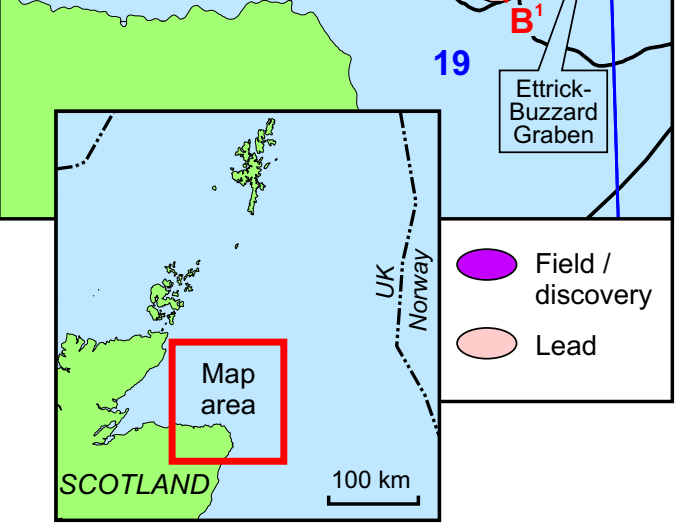

B

(c)

$B^{1}$

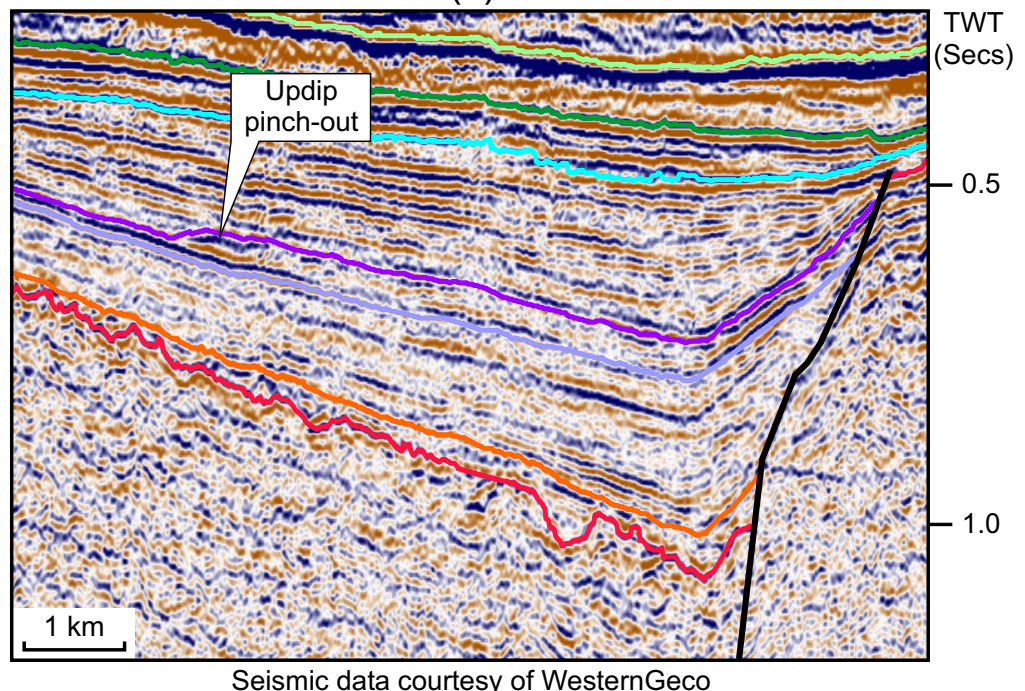

Seismic data courtesy of WesternGeco 

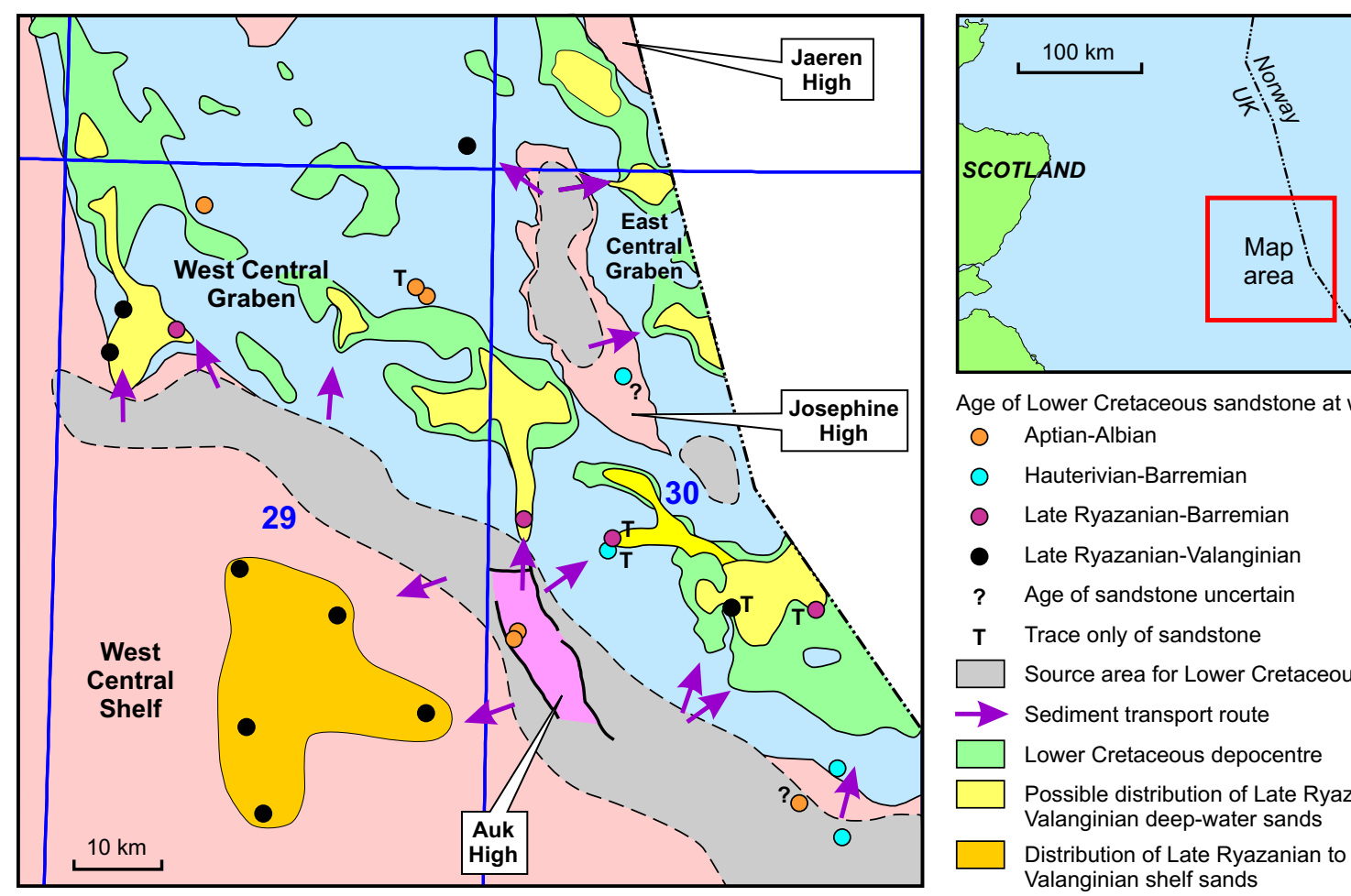

Age of Lower Cretaceous sandstone at well

○ Aptian-Albian

O Hauterivian-Barremian

- Late Ryazanian-Barremian

- Late Ryazanian-Valanginian

? Age of sandstone uncertain

T Trace only of sandstone

Source area for Lower Cretaceous sands Sediment transport route

Lower Cretaceous depocentre

Possible distribution of Late Ryazanian to Valanginian deep-water sands

Distribution of Late Ryazanian to Valanginian shelf sands 


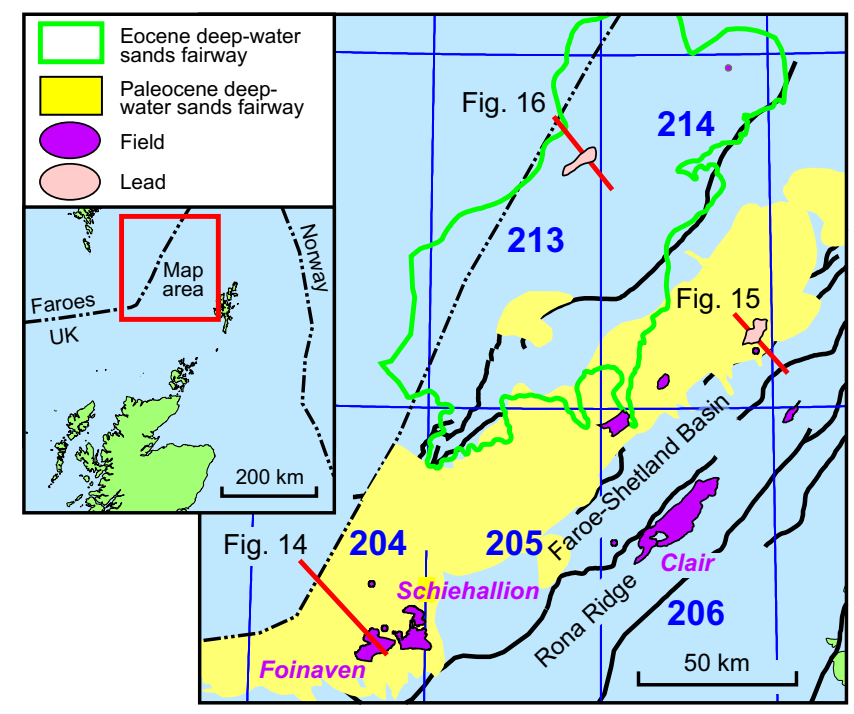




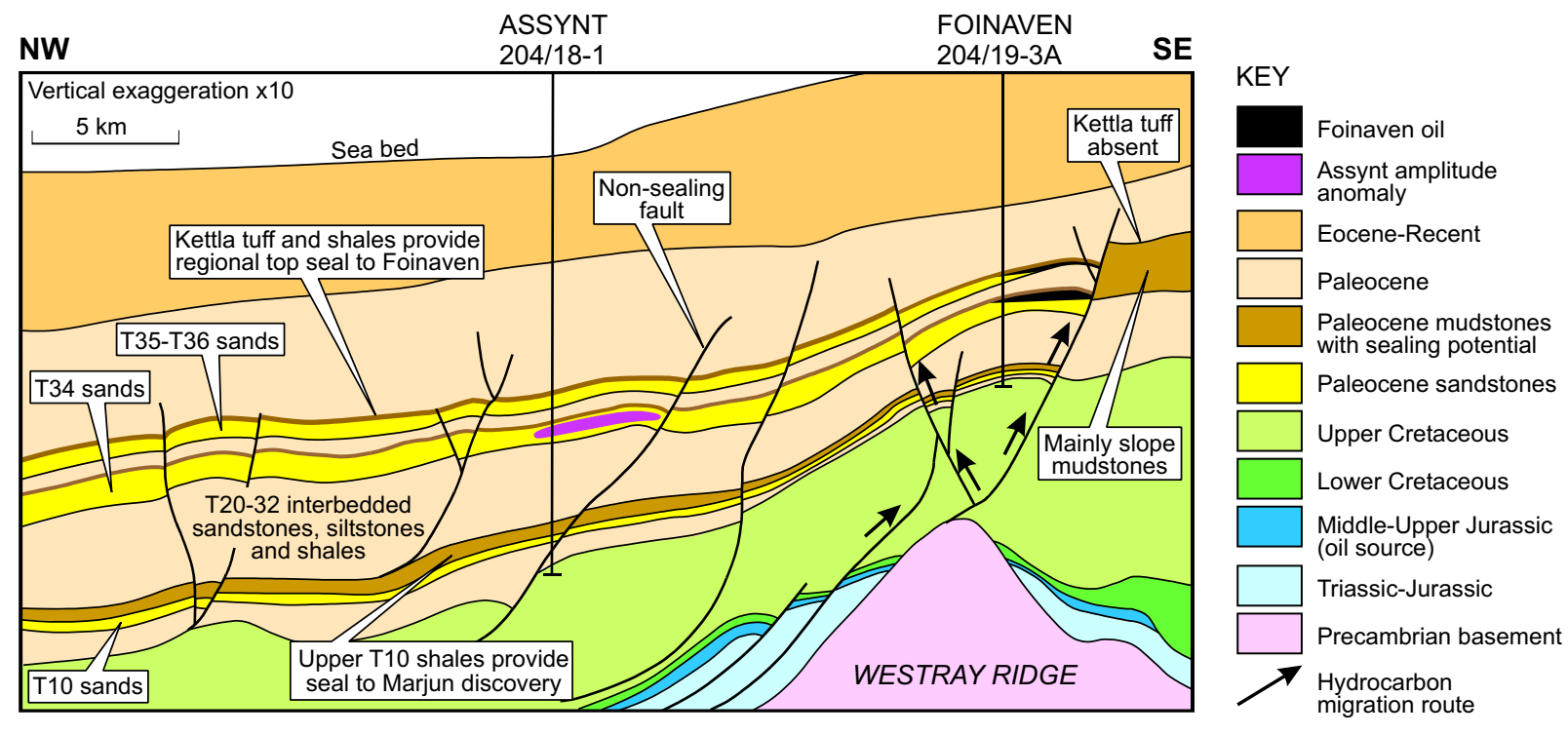




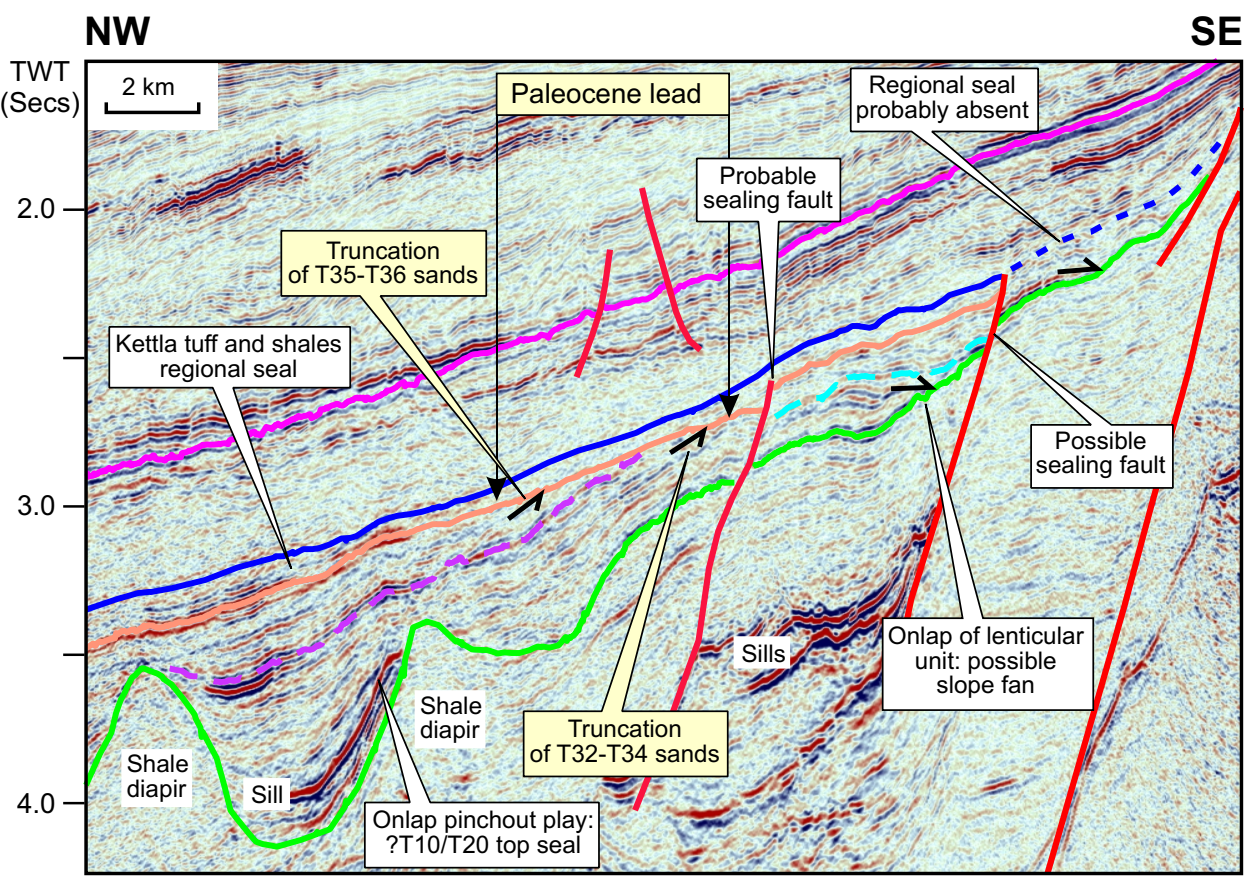

Released Shell seismic data available from PGS Geophysical
SE

\begin{tabular}{|ll|}
\hline KEY & \\
& Top Balder Formation \\
& Top Kettla Member \\
& Base regional seal \\
& Top T32-T34 sands \\
& Intra-Paleocene \\
& Base Tertiary \\
$\mathbf{L}$ & Truncation \\
$\mathbf{L}$ & Onlap
\end{tabular}




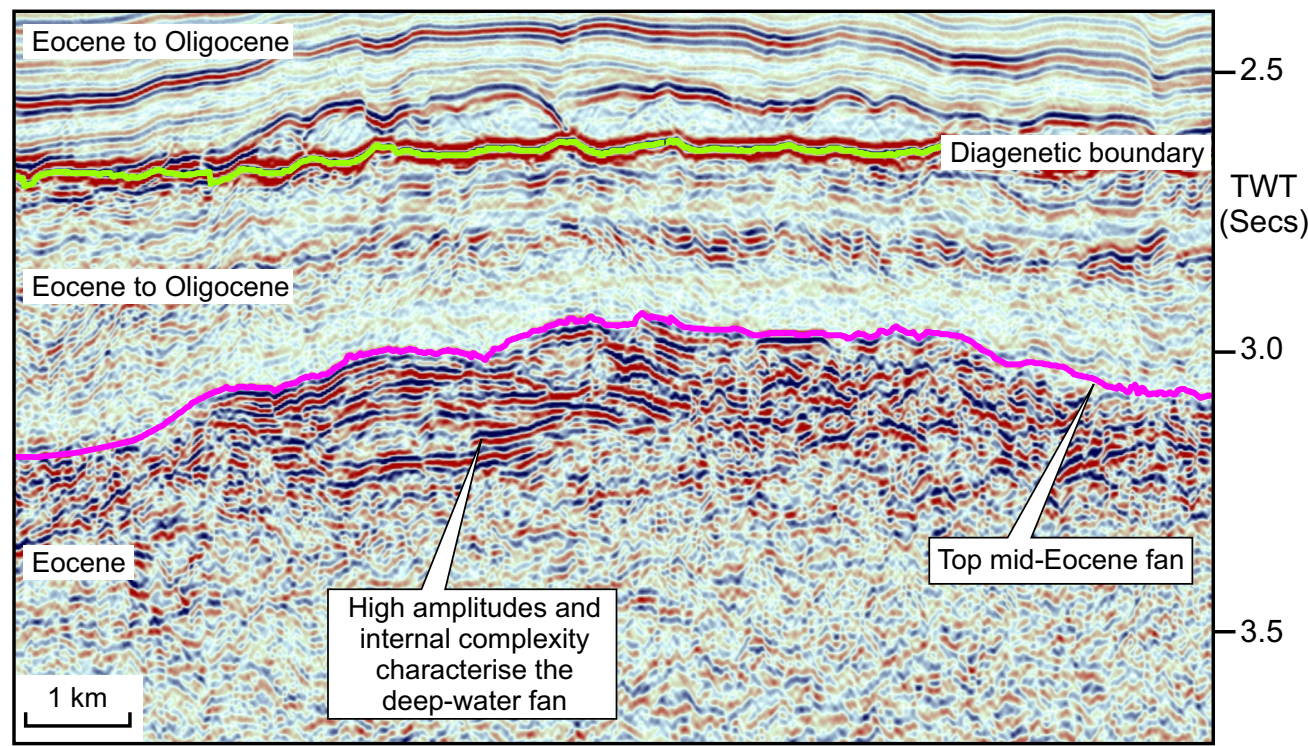

Seismic data courtesy of Fugro Multi Client Services 